\title{
THE ECONOMY OF THE BELGIAN REGIONS TESTED WITH MULTIMOORA
}

\author{
Willem Karel M. Brauers ${ }^{1}$, Romualdas Ginevičius ${ }^{2}$ \\ ${ }^{1}$ Faculty of Applied Economics, University of Antwerp, Belgium \\ ${ }^{2}$ Department of Enterprise Economics and Business Management, \\ Vilnius Gediminas Technical University, Saulètekio al. 11, 10223 Vilnius, Lithuania

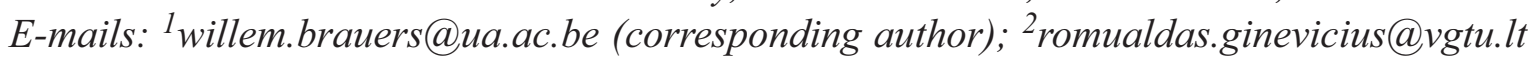

Received 20 March 2009, accepted 15 February 2010

\begin{abstract}
The definition of robustness in econometrics, the error term in a linear equation, was not only broadened, but in addition moved to the meaning of common language: from a cardinal to a qualitative one. At that moment the most robust Multi-Objective Optimization Method has to fulfill seven essential conditions. In addition, considering all stakeholders involved, the choice of the objectives is non-subjective with the assistance of the Ameliorated Nominal Group Technique and the Delphi method. Outside Normalization is not necessary by the use of a Full Multiplicative Form or of MOORA (MultiObjective Optimization by Ratio Analysis). This last one is composed of ratio analysis "senso stricto" and of the Reference Point Method with the previously obtained ratios as a starting point. Combining the three methods in MULTIMOORA a full guarantee for robustness in Multiple Objectives Optimization is offered. This interpretation is tested by an application to the Economy of the Belgian Regions.
\end{abstract}

Keywords: robustness, Multi-Objective Optimization, stakeholders, Ameliorated Nominal Group Technique, Delphi method, Full Multiplicative Form, MOORA, MULTIMOORA.

Reference to this paper should be made as follows: Brauers, W. K. M.; Ginevičius, R. 2010. The Economy of the Belgian Regions tested with MULTIMOORA, Journal of Business Economics and Management 11(2): 173-209.

\section{Introduction}

The economy of the three Belgian Regions will be tested with MULTIMOORA, an approach which combines three methods of multi-objective optimization controlling each other: ratio systems, reference point method and the full multiplicative form. At that moment these Multi-Objective Optimization Methods have to fulfill as much as possible essential conditions of robustness. What is here meant by robustness?

By 1953, which is quite recent for statistics (as well known, statistics already existed in Roman times with the census of population), robust became a statistical term as "strong, healthy, sufficiently tough to withstand life's adversities" (Stigler 1973: 872). Nevertheless, already in 1969, statistician Huber (1969) considered robustness as purely cardinal: 
as a compromise between a normal distribution and its light deviations. At a later time Huber (1981) wrote a more complete book on Robust Statistics. In 1994 on the occasion of Huber's birthday his colleagues edited a book on Robust Statistics (Rieder 1996). More recently the statisticians Casella and Berger (2002) call a robust alternative the Median Absolute Deviation for a sample $X_{1}, \ldots \ldots, X_{n}(2002: 509)$.

The error term in a linear equation is the starting point for the definition of robustness in econometrics (Darnell 1997: 355). In addition robustness is not only linked to error terms or random variables but also to residual terms, slack and dummy variables, outliers etc. Darnell concludes: "given the somewhat arbitrary ad hoc nature of the robust estimators ......these approaches have had limited application in econometrics" (Darnell 1997: 356). Kennedy (1998) recognizes the existence of robust estimators: "an estimator whose properties while not quite best..." (Kennedy 1998: 298), he continues "the topic of robustness has become quite popular recently in econometrics, as researchers have become aware of the extreme sensitivity of some of their estimation procedures". Other well-known textbooks on econometrics do not even mention the name of robustness, like Thomas (1985), Intriligator (1978), Madansky (1976), Walters (1973), Wonnacott and Wonnacott (1970) and Johnston (1963). More specificity is found by authors who consider robustness in forms of the error distribution like Rhodes and Fomby (1988), Carter Hill et al. (2008) and Verbeek (2008). A certain similarity can be found in Robust Control Theory of engineering where Loss Functions determine uncontrollable variations in product quality (Taguchi 1993).

Mills (1992) presents a Bayesian prediction test which is robust to certain forms of non-normality in the error distribution. Moreover, from the beginning Bayesian Analysis has to be characterized as cardinal, nevertheless with a high grade of arbitrariness. This arbitrariness could be softened by considerations on robustness ${ }^{1}$. Anyway, cardinal numbers form also the basis of robustness in the Poisson Distribution, the t statistic and in Sampling (Särndal et al. 1992).

However, we observe a move to a more vague and qualitative definition of robustness, namely to the meaning of common language (Webster's new Universal Unabridged Dictionary for robust: strong; stronger, strongest), from a cardinal towards a qualitative scale: the most robust one, more robust than..., as robust as....., robust, weak robust, less robust than..., not robust etc., comparable to so many other scales in multi-objective analysis, for instance mentioned by Brauers (2004: 97-99).

A debate between Frisch (1933) and Tinbergen (1930) ensued as whether or not Tinbergen had estimated structural form representations robust to changes in policy regimes or reduced form representations not robust to shifting policy regimes (Heckman 1992: 878). Kreps (1990) maintains that more robustness is more important for bargaining theory than for auction theory as more information is available in the latter case than in the former. He esteems that robust predictions are crucial although the meaning given to robustness may depend on the context (also Vincke 1999: 186(2)). Edin and Ohlson

${ }^{1}$ A good overview of the problem of Robustness and Bayesian Analysis is brought by Ruggeri (2008). 
(1991) examine that institutional arrangements in the political process affect budget deficits. Sensitivity Analysis indicates that the results are robust. Admati and Pfleiderer (1994) speak of robustness in financial contracting. Another qualitative approach of robustness is related to subjective probability by Machina and Schmeidler (1992). Dasgupta and Maskin (2008) maintain that the simple majority rule is the most robust voting rule. Finally, the context will determine robustness in benchmarking, in scenario writing and in simulation (Brauers and Zavadskas 2010).

Concluding on the remark that significance of robustness depends on the context can be specified in different ways. First, robustness can be considered cardinal or qualitative. Second, if robustness is indicated as vague or arbitrary is it also not the case with inference statistics Hoel (1971: 2) versus Hays (1974: 47) and Casella and Berger (2002: VII), probability theory (Hays 1974: 47) and statistical specification [Intriligator (1978: 2); Matyas and Sevestre (1992: chapter 9) versus Thomas (1985: 71); Wonnacott and Wonnacott (1970: 312)]? Third, robustness is characterized by completeness being present in the statistical population, when defined as covering events and opinions which are present, as well as in the statistical universe with events and opinions not only present but also possible (Brauers and Zavadskas 2010). Consequently, this completeness of robustness justifies also the making of a link with Multi-Objective Methods.

\section{Conditions of Robustness in Multi-Objective Methods}

For the researcher in multi-objective decision support systems the choice between many methods is not very easy. Indeed numerous theories were developed since the forerunners: Condorcet (1785: LVIII) [the Condorcet Paradox, against binary comparisons], Gossen (1853) [law of decreasing marginal utility], Minkowsky (1896: 1911) [Reference Point] and Pareto (1906) [Pareto Optimum and Indifference Curves analysis] and pioneers like Kendall [ordinal scales, since 1948], Roy et al. [ELECTRE since 1966], Miller and Starr [Multiplicative Form for multiple objectives, 1969], Hwang and Yoon [TOPSIS since 1981] and Saaty [AHP since 1988].

We intend to assist the researcher with some guidelines for an effective choice. In order to distinguish the different multi-objective methods from each other we use the qualitative definition of robustness.

The most robust multi-objective method has to satisfy the following conditions.

1) The method of multiple objectives in which all stakeholders are involved is more robust than this one with only one decision maker or different decision makers defending their own limited number of objectives. All stakeholders mean everybody interested in a certain issue. Consequently, the method of multiple objectives has to take into consideration consumer sovereignty.

The method taking into consideration consumer sovereignty is more robust than this one which does not respect consumer sovereignty. Community indifference loci measure consumer sovereignty. Solutions have to deliver points inside the zone of the highest possible community indifference locus (Brauers 2008b). 
2) The method of multiple objectives in which all non-correlated objectives are considered is more robust than this one considering only a limited number of objectives.

3) The method of multiple objectives in which all interrelations between objectives and alternatives are taken into consideration at the same time is more robust than this one with interrelations only examined two by two.

4) The method of multiple objectives which is non-subjective is more robust than this one which uses subjective estimations for the choice and importance of the objectives and for normalization.

\section{1) For the choice of the objectives}

A complete set of representative and robust objectives is found after Ameliorated Nominal Group Technique Sessions with all the stakeholders concerned or with their representative experts.

\section{2) For giving importance to an objective}

With weights and scores importance of objectives is mixed with normalization. On the contrary, Delphi can determine the importance of objectives separately from normalization. In addition, as all stakeholders concerned are involved, the Delphi method is non-subjective.

\section{3) For Normalization}

The method of multiple objectives which does not need external normalization is more robust than this one which needs a subjective external normalization (Brauers 2007). Consequently, the method of multiple objectives which uses non-subjective dimensionless measures without normalization is more robust than this one which uses subjective weights [weights were already introduced by Churchman et al. $(1954,1957)$ ] or subjective non-additive scores like in the traditional reference point theory (Brauers 2004: 158-159).

5) The method of multiple objectives based on cardinal numbers is more robust than this one based on ordinal numbers: "an ordinal number is one that indicates order or position in a series, like first, second, etc." (Kendall and Gibbons 1990: 1). Robustness of cardinal numbers is based first on the saying of Arrow (1974: 256): "Obviously, a cardinal utility implies an ordinal preference but not vice versa" and second on the fact that the four essential operations of arithmetic: adding, subtracting, multiplication and division are only reserved for cardinal numbers.

6) The method of multiple objectives which uses the last recent available data as a base is more robust than this one based on earlier data.

7) Once the previous six conditions fulfilled the use of two different methods of multiobjective optimization is more robust than the use of a single method; the use of three methods is more robust than the use of two, etc.

In order to define robustness successively the following points are discussed:

- the Ameliorated Nominal Group Technique,

- the origin of Alternatives, 
- the Delphi Method,

- the Multiplicative Form,

- the Multi-Objective Optimization by Ratio Analysis Method (MOORA) composed of two methods: ratio analysis and reference point theory starting from the previous found ratios,

- MULTIMOORA composed of the Multiplicative Form and of MOORA, i.e. the combination of three methods. At that moment, we shall see if all conditions of robustness are fulfilled and namely on the basis of the economy of the Belgian regions.

\section{The Ameliorated Nominal Group Technique as a source for objectives}

\subsection{The original Nominal Group Technique of Van de Ven and Delbecq (1971)}

A group of especially knowledgeable individuals (experts), representing all stakeholders, is formed, which comes together in a closed meeting. A steering panel or a panel leader leads the group.

The nominal group technique consists of a sequence of steps, each of which has been designed to achieve a specific purpose.

1) The steering group or the panel leader carefully phrases as a question the problem to be researched. Much of the success of the technique hinges around a wellphrased question. Otherwise the exercise can easily yield a collection of truisms and obvious statements. A successful question is quite specific and refers to real problems. The question has to have a singular meaning and a quantitative form as much as possible.

2) The steering group or the panel leader explains the technique to the audience. This group of participants is asked to generate and write down ideas about the problem under examination. These ideas too have to have a singular meaning and a quantitative form as much as possible. Participants do not discuss their ideas with each other at this stage. This stage lasts between five and twenty minutes.

3) Each person in round-robin fashion produces one idea from his own list and eventually gives further details. Other rounds are organized until all ideas are recorded.

4) The steering group or the panel leader will discuss with the participants the overlapping of the ideas and the final wording of the ideas.

5) The nominal voting consists of the selection of priorities, rating by each participant separately, while the outcome is the totality of the individual votes. A usual procedure consists of the choice by each participant of the $n$ best ideas from his point of view, with the best idea receiving $\mathrm{n}$ points and the lowest one a point. All the points of the group are added up. Ranking is the democratic result for the whole group.

\subsection{The Ameliorated Nominal Group Technique of Brauers (1987)}

6) Out of experience, one may say that there is still much wishful thinking, even between experts. Therefore the group was also questioned about the probability 
of occurrence of the event. In this way they became more critical even about their own ideas. The probability of the group is found as the median of the individual probabilities.

7) Finally, the group rating $(\mathrm{R})$ is multiplied with the group probability $(\mathrm{P})$ in order to obtain the effectiveness rate of the event $(\mathrm{E})$ :

$$
R x P=E
$$

Once again, the effectiveness rates of the group are ordered by ranking. Experience proves that the introduction of probabilities decreases significantly the total number of points.

\section{The origin of Alternatives}

Project information for interested parties has to be as intensive as possible. Otherwise imagination has to be intensive eventually with the assistance of the Ameliorated Nominal Group Technique.

Some of the candidate alternatives are excluded if they do not respond to conditions concerning lower bounds or upper limits. All constraints concerning lower bounds or upper limits have to be hard constraints, which form a sine qua non for the acceptance of the candidate alternatives (Wierzbicki and Makowski 1992: 4).

Distinction has to be made between qualitative and quantitative hard constraints. On the one hand, investments needed in a well-defined region and not in other regions, complete financial guarantees to be given for daughters of multinationals in case of failure, represent examples of qualitative hard constraints.

On the other side, certain capacities in production not to be exceeded unless new investments are made, the World Bank granting a loan to a developing country unless an Internal Rate of Return of $12 \%$ is guaranteed, geometrical constraints under the form of a limiting line, surface or manifold, represent examples of quantitative hard constraints.

\section{The Delphi Technique to determine the importance of an objective}

Delphi, so named after the Greek oracle, was first thought of as a tool for better forecasting. In this sense, it seems that the first experiments took place around 1948 (Quade and Boucher 1968: 334). Today Delphi is no longer limited to forecasting alone. Dalkey and Helmer (1963) at RAND Corporation first used Delphi in its present form around 1953.

The Delphi Method is a method for obtaining and processing judgmental data. It consists of a sequenced program of interrogation (in session or by mail) interspersed with feedback of persons interested in the issue, while everything is conducted through a steering group.

The essential features of Delphi are the following:

1) the rather vague notion "persons interested in the issue" is interpreted by Quade 
(1970: 9-10) as follows; "In practice, the group would consist of experts or especially knowledgeable individuals, possibly including responsible decision makers";

2) the steering group treats anonymously the sources of each input;

3) inputs should possess as much as possible a single meaning and a quantitative form. The inputs with these characteristics are elicited with feedback in a series of rounds;

4) opinions about the inputs are evaluated with statistical indexes such as median and quartiles;

5) there is also a feedback of the statistical indexes with a request for re-estimation after consideration of reasons for extreme positions. The practice of Delphi reveals that after several rounds convergence is shown between the various opinions (one of the main advantages of the Delphi method);

6) there are two developments of Delphi: one is based on a meeting, the other on the sending of questionnaires. The organization of a meeting produces quicker results; the meeting, however, has to be organized in such a way that communication between the panel members is impossible. In order to speed up the meeting an on-line computer could be installed. Everybody involved in the Delphi teamwork would have a desk terminal linked to a computer and would be able to look at a television screen giving the results calculated by the computer.

Convergence in opinion between all stakeholders allowing to give more importance to objective results from a Delphi exercise, which could provide the given objective with a Significance Coefficient.

For instance, giving a significance coefficient to pollution abatement, the stakeholders are asked to give the following importance to pollution abatement:

$$
0,1,2 \text { or } 3 \text {. }
$$

Suppose that after several rounds convergence is reached on 3. [Brauers (2008a: 170173) brings a more detailed application].

The Attribution of Sub-Objectives represents another solution. The Attribution Method is more refined than the Coefficient Method as the attribution method succeeds in characterizing an objective better. For instance, instead of giving a significance coefficient of three to pollution abatement the objective "pollution abatement" is divided into three sub-objectives: the Greenhouse Effect, Energy Consumption and Other Pollution, each with their own characteristics.

\section{The Full-Multiplicative Form}

The following n-power form is called from now on a full-multiplicative form in order to distinguish it from other rather mixed forms, namely mixed with additive forms (for more details see: Keeney and Raiffa 1993: 234): 


$$
U_{j=} \prod_{i=1}^{n} x_{i j}
$$

with: $j=1,2, \ldots, m ; m=$ the number of alternatives; $i=1,2, \ldots, n ; n$ being the number of objectives; $x_{i j}=$ response of alternative $j$ on objective $i$; $U_{j}=$ overall utility of alternative $j$.

The overall utilities $\left(\mathrm{U}_{\mathrm{j}}\right)$, obtained by multiplication of different units of measurement, become dimensionless.

Stressing the importance of an objective can be done by adding an $\alpha$-term or by allocating an exponent (a Significance Coefficient) on condition that this is done with unanimity or at least with a strong convergence in opinion of all the stakeholders concerned. Therefore, a Delphi exercise may help.

How is it possible to combine a minimization problem with the maximization of the other objectives? Therefore, the objectives to be minimized are denominators in the formula:

$$
U_{j}^{\prime}=\frac{A_{j}}{B_{j}},
$$

$$
\text { with: } \quad A_{j}=\prod_{g=1}^{i} x_{g i} \text {, }
$$

$j=1,2, \ldots, m ; m=$ the number of alternatives; $i=$ the number of objectives to be maximized

$$
\text { with: } \quad B_{j}=\prod_{k=i=1}^{n} x_{k j} \text {, }
$$

$n-i=$ the number of objectives to be minimized,

with: $U_{j}$ ': the utility of alternative $j$ with objectives to be maximized and objectives to be minimized.

\section{The Full-Multiplicative Form and the Economy of the Belgian Regions}

On the one side the seven conditions for the most robust multi-objective method present a theoretical construction, an ideal to be aimed at. On the other side some Regional Statistics suitable for our purpose are missing in Belgium.

A note on terminology is needed to clarify this issue. Gross Domestic Product (GDP) 
in a certain year is the value added created on the national territory, being a territorial concept. On the contrary, Gross National Product (GNP) is the value added created by the civilians and the permanent residents of a nation. Interpolated for a region, the Gross Regional Domestic Product (GRDP) signifies the value added created on a regional territory during a given year and the Gross Regional Product (GRP) means the value added created by the permanent residents of a region during that year.

In addition, transfer payments are a transfer of value added from one group of the population to another group, from one region to another or from one nation to another one. Consequently Transfer Payments are not included in GRP or GNP but are considered in a Disposable Income. Finally the National Public Debt has to be broken down in the Public Debt of the regions ${ }^{2}$.

For the first time the Center for Economic Studies of Leuven University estimated the transfer payments between the Belgian regions (Van Rompuy and Bilsen 1988). On the basis of this study KBC, Asset Management continued the work for more recent years (Van Gompel and Van Craeynest 2003). Table 1 summarizes the transfer payments from 1990 until 2005.

Table 1. Total transfer payments in Public Finance (in billion $€$ )

\begin{tabular}{c|c|c|c}
\hline & Flanders & Wallonia & Brussels \\
\hline 1990 & 3.76 & -2.61 & -1.15 \\
\hline 1995 & 4.49 & -3.33 & -1.16 \\
\hline $1996^{(\mathrm{a})}$ & 4.57 & -3.38 & -1.19 \\
\hline 1997 & 4.71 & -3.73 & -0.98 \\
\hline 1998 & 4.62 & -3.79 & -0.83 \\
\hline 1999 & 4.68 & -3.88 & -0.80. \\
\hline 2000 & 4.88 & -4.11 & -0.77 \\
\hline $2001^{(\mathrm{b})}$ & 5.27 & -4.36 & -0.91 \\
\hline 2002 & 5.44 & -4.44 & -1.00 \\
\hline $2005^{(\mathrm{c})}$ & 5.84 & -6.06 & 0.21 \\
\hline
\end{tabular}

(a) W. Brauers, Het Bruto Regionaal Product van Vlaanderen. Wallonië en Brussel, UA, Faculteit Toegepaste Economische Wetenschappen, p.17 obtains for: Flanders 4.63bn.

2 Since 1999 the National Bank of Belgium provides statistics on the Regional Private Incomes (also called primary incomes of the households) but neither on the Gross Regional Domestic Products (which involves the problem of the important commuter flows to Brussels) nor on the Gross Regional Products. To close the gap to GRP one would need to know: the cash flows of Belgian companies before taxes but after distribution of dividends and the indirect taxation. This link is missing as Regional Statistics are dictated by Europe, but Europe is not interested in the national point of view as found in GNP and GRP. The GRP's could be estimated after a method explained for 1996 (Brauers 1999a). However, here to simplify terminology we assume that the GRP equals the Regional Private Income. 
$€$, Wallonia - 3.81bn.€ and for Brussels 0.82bn.€, but including interest payments: $6.11 \mathrm{bn} . €-5.31 \mathrm{bn} €-0.80 \mathrm{bn} €$. At that moment P. Kestens (ULB) arrives at $6 \%$ of the Gross Regional Product of Flanders, certainly a high figure (Divorce a la belge; l'économie dit non. Le séparatisme vu par des académiques, des patrons et des syndicalistes, Eco-Soir, 9/25/1992.).

(b) Since the end of 2000 the influence of the Lambermont Agreement plays: more money is given to the French speaking Community to finance their school system.

(c) Dury et al. 2008.

Facing the Maastricht norm (May 1997) for the Public Debt of 60\% of GDP, Belgium obtained an exception at $122.2 \%$, on condition that this figure would go down to $60 \%$ as soon as possible ${ }^{3}$. The successive Belgian governments failed to fulfill this target. The lowest point was reached in 2007 at $84 \%$, at the moment of a for Belgium high economic growth. Since then the figure increased again as the economic situation deteriorated. After the estimations of the Belgian Department of Finance (Documentatieblad) the public debt will continue to rise (Table 2).

Table 2. Evolution of the Belgian Public Debt as a \% of GDP

\begin{tabular}{c|c}
\hline 1993 peak & 133.5 \\
\hline 1997 Maastricht & 122.2 \\
\hline 2005 & 91.5 \\
\hline 2006 & 88.2 \\
\hline 2007 (lowest $\%$ ) & 84 \\
\hline 2008 & 89.7 \\
\hline 2009 & 97.5 \\
\hline 2010 & 101.9 \\
\hline 2011 & 103.9 \\
\hline 2012 (new peak) & 104.3 \\
\hline 2013 & 103.4 \\
\hline 2014 & 101.0 \\
\hline 2015 & 97.4 \\
\hline
\end{tabular}

The high public debt of Belgium is mainly due to what is called a "waffle- iron policy"; a Belgian waffle has to be turned around such that both sides of the waffle are baked in an equal way. The same occurred for the Belgian policy.

If Flanders received funds from the national treasury to support its economic expansion, Wallonia wanted to receive an equal amount without any economic need. The funds at the Flemish side were mostly based on the economic calculus but not at the Walloon one. On the other side, Wallonia asks transfer payments (gifts) from Flanders: "do not kill the goose that lays the golden eggs".

${ }^{3}$ The Maastricht criteria to join the EMU were roughly as follows:

- Inflation: $\max 2 \%$

- Deficit Public Budget: max 3\% of the Gross Domestic Product (GDP)

- Public Debt smaller than $60 \%$ of GDP. 
It would not be difficult to estimate the non-effective investments of the past and to allot them to the regions. This partition on historical grounds could mean bankruptcy for Wallonia. Therefore from the Flemish side the suggestion could come to divide the National Public Debt otherwise.

It could be the result of a computation, for instance:

- 1/3 from the Gross Regional Product (GRP estimated)

Flanders $\quad 60.9 \%$

Brussels $\quad 9.5 \%$

Wallonia $\quad 29.6 \%$

$-1 / 3$ from population

Flanders $\quad 58.0 \%$

Brussels $\quad 9.3 \%$

Wallonia $\quad 32.7 \%$

$-1 / 3$ from territory

Flanders $\quad 44.29 \%$

Brussels $\quad 0.53 \%$

Wallonia $\quad 55.18 \%$

TOTAL

- Flanders $\quad 54.40 \%$

- Brussels $\quad 6.44 \%$

- Wallonia $\quad 39.16 \%$

This is extremely favourable for Brussels but very unfavourable for Wallonia and ipso facto not acceptable. More equilibrated proportions are obtained if the surface of each territory is left out.

- 1/2 from the Gross Regional Product (GRP):

Flanders $\quad 60.9 \%$

Brussels $\quad 9.50 \%$

Wallonia $29.6 \%$

- 1/2 from population:

Flanders $\quad 58.0 \%$

Brussels $\quad 9.30 \%$

Wallonia $\quad 32.7 \%$

- TOTAL

Flanders $\quad 59.45 \%$

Brussels $\quad 9.40 \%$

Wallonia $\quad 31.15 \%$ 
Going out from the Maastricht-norm of a National Public Debt of $122.2 \%$ of GDP the repartition over the regions would be as follows:

$\begin{array}{ll}\text { Flanders } & 116.4 \% \text { of its GRP } \\ \text { Brussels } & 120.6 \% \text { of its GRP } \\ \text { Wallonia } & 134.6 \% \text { of its GRP }\end{array}$

In table 3 different scenarios were taken into account as a basis for the starting point of Maastricht, which we call from now on the year zero like one speaks of ground zero meaning a new begin.

Table 3. Matrix of Responses of Scenarios on Objectives for the Belgian Regions at the Maastricht moment (a)

\begin{tabular}{|c|c|c|c|c|c|c|c|}
\hline & 1 & 2 & 3 & 4 & 5 & 6 & 7 \\
\hline Scenarios & \begin{tabular}{|c|} 
WALLONIA \\
Disposable \\
Y /head \\
(in BEF)
\end{tabular} & $\begin{array}{c}\text { BRUSSELS } \\
\text { Disposable } \\
\text { Y/head } \\
\text { (in BEF) }\end{array}$ & $\begin{array}{c}\text { FLANDERS } \\
\text { Disposable } \\
\text { Y./head } \\
\text { (in BEF) }\end{array}$ & \begin{tabular}{|c|} 
TRANSFERS \\
from \\
Flanders / \\
head \\
(in BEF)
\end{tabular} & \begin{tabular}{|c|} 
FLANDERS \\
Public Debt \\
$\%$ of GRP
\end{tabular} & $\begin{array}{c}\text { WALLONIA } \\
\text { Public Debt } \\
\% \text { of GRP }\end{array}$ & $\begin{array}{l}\text { BRUSSELS } \\
\text { Public Debt } \\
\% \text { of GRP }\end{array}$ \\
\hline & MAX & MAX & MAX & MIN & MIN & MIN & MIN \\
\hline Scenario 0 & 692883 & 698809 & 676743 & 41771 & 122.2 & 122.2 & 122.2 \\
\hline Scenario 1 & 684076 & 684076 & 684076 & 34438 & 122.2 & 122.2 & 122.2 \\
\hline Scenario 2 & 657935 & 680457 & 699375 & 19139 & 122.2 & 122.2 & 122.2 \\
\hline Scenario 3 & 674574 & 699861 & 686881 & 31633 & 116.4 & 134.6 & 120.6 \\
\hline Scenario 4 & 657935 & 680457 & 699375 & 19139 & 116.4 & 134.6 & 120.6 \\
\hline Scenario 5 & 684076 & 684076 & 684076 & 34438 & 116.4 & 134.6 & 120.6 \\
\hline Scenario 6 & 692883 & 698809 & 676743 & 41771 & 116.4 & 134.6 & 120.6 \\
\hline Scenario 7 & 628380 & 664936 & 718514 & 0 & 122.2 & 122.2 & 122.2 \\
\hline Scenario 8 & 628380 & 664936 & 718514 & 0 & 116.4 & 134.6 & 120.6 \\
\hline Scenario 9 & 718514 & 718514 & 718514 & 0 & 122.2 & 122.2 & 122.2 \\
\hline Scenario10 & 718514 & 718514 & 718514 & 0 & 116.4 & 134.6 & 120.6 \\
\hline
\end{tabular}

(a) calculations come from Brauers (1999b).

$1 \mathrm{BEF}=0.0247893 €$

Suppose that the following objectives are advanced with the scenarios as alternatives:

- maximization of:

Disposable Income per head for Wallonia

Brussels

Flanders

- minimization of:

Transfer payments from Flanders

Public Debt of Flanders as a \% of its GRP 
Public Debt of Wallonia as a \% of its GRP

Public Debt of Brussels as a \% of its GRP

The following scenarios are foreseen:

\section{Scenario 0: the Scenario of the Status Quo}

Scenario 0 shows the status quo with a strong Income Paradox disfavouring Flanders, the highest transfer payments from Flanders and a huge solidarity of Flanders to support a part of the national public debt normally attributed to Wallonia and Brussels.

Scenario I: the Scenario of the Average Belgian

Compared to Scenario 0 the transfer payments are diminished in such a way that the Income Paradox disappears and that the average Belgian has the same income everywhere. Solidarity remains for the National Public Debt.

\section{Scenario II: the Scenario of an Unfavourable Growth Rate for Flanders}

Due to an unfavourable growth rate Flanders diminishes the transfer payments but at the same time the Income Paradox disappears. Nevertheless the solidarity in the national public debt remains.

Scenario III: the Scenario in which Flanders asks for the Partition of the National Public Debt

Flanders not only contributes to transfer payments but also pays interest charges on a part of the national public debt for which it is not responsible. Therefore Flanders asks for the partition of the national public debt.

Flanders is not demanding the reimbursement of the too high part of the interest payments from the past on the national public debt. It agrees on the repartition of the national public debt on the basis of the GRP's and the population and not on historical grounds.

Scenario IV: the Scenario of an Unfavourable Growth Rate for Flanders and at that moment asks also for the Partition of the National Public Debt

Due to an unfavourable growth rate Flanders diminishes the transfer payments and at the same time asks for the Partition of the National Public Debt.

Scenario V: the Scenario of the Average Belgian but as compensation Flanders asks for the Partition of the National Public Debt

The transfer payments are slightly diminished in such a way that the Income Paradox disappears and that the average Belgian has the same income everywhere, but as compensation Flanders asks for the Partition of the National Public Debt.

Scenario VI: the Scenario where Flanders asks for the Partition of the National Public Debt

Flanders asks for the Partition of the National Public Debt but the transfer payments remain high and consequently the Income Paradox reappears.

Scenario VII: the Scenario of Solidarity only for the Partition of the National Public Debt

The transfer payments disappear but solidarity remains for the National Public Debt. 


\section{Scenario VIII: the Scenario of no Solidarity at all}

The transfer payments disappear and no solidarity remains for the National Public Debt.

\section{Scenario IX: the Scenario of an Optimal Economic Policy in Wallonia}

The transfer payments are no more needed as Wallonia and also Brussels come at the economic level of Flanders.

\section{Scenario X: the Scenario where the Optimal Economic Policy in Wallonia even agrees on the Partition of the National Public Debt}

The transfer payments are no more needed as Wallonia and also Brussels come at the economic level of Flanders and even more, they agree on the Partition of the National Public Debt.

Table 4. Ranking of the Scenarios by the Full-Multiplicative Method at the Year Zero

\begin{tabular}{c|c|c|c}
\hline 1 & Scenario IX & Optimal Economic Policy in Wallonia and Brussels & 203,267 \\
\hline 2 & Scenario X & $\begin{array}{c}\text { Optimal Economic Policy in Wallonia and Brussels even } \\
\text { agreeing on the Partition of the National Public Debt }\end{array}$ & 196,306 \\
\hline 3 & Scenario VII & Flanders asks for the Partition of the National Public Debt & 164,515 \\
\hline 4 & Scenario VIII & No Solidarity at all & 158,881 \\
\hline 5 & Scenario II & Unfavourable Growth Rate for Flanders & 90 \\
\hline 6 & Scenario IV & $\begin{array}{r}\text { Unfavourable Growth Rate for Flanders and at that } \\
\text { moment asks also for the Partition of the National Public }\end{array}$ & 87 \\
\hline 7 & Scenario III & Partition of the National Public Debt & 54 \\
\hline 8 & Scenario I & the Average Belgian & 51 \\
\hline 9 & Scenario V & $\begin{array}{r}\text { Average Belgian but as compensation Flanders asks for } \\
\text { the Partition of the National Public Debt }\end{array}$ & 49 \\
\hline 10 & Scenario O & Status Quo & 43 \\
\hline 11 & Scenario VI & $\begin{array}{r}\text { Flanders asks for the Partition of the National Public Debt } \\
\hline\end{array}$ & 42 \\
\hline
\end{tabular}

In table 4 the saying of Arrow (1974: 256) is of application: "Obviously, a cardinal utility implies an ordinal preference but not vice versa", whereas the ordinal preference does not only play on the first but also on the last column. The Full Multiplicative Form results in dimensionless numbers without cardinal meaning. Nevertheless the split between the first four rankings, namely until Scenario VIII, and the other ones is meaningful.

Due to the necessary numerous calculations we do not update the Maastricht version. Anyway the illustration is certainly valuable. Does the exercise satisfy the aforesaid robust conditions? 
Concerning the first and second condition of robustness, if not all stakeholders are involved, the authors tried to be as complete as possible for the objectives of a welfare economy. It is true that a well-being economy with objectives on security, health care, justice, education, ecology and leisure is not covered. In addition, the method taking into consideration consumer sovereignty is more robust than this one which does not respect consumer sovereignty, which is certainly here the case as the main part of the application is reserved for the disposable income of the households.

Third condition: all interrelations between objectives and alternatives are taken into consideration at the same time and not two by two.

Fourth condition: the choice of objectives already discussed above can be designated as robust inside certain limits. No special attention was given to one or another objective; all objectives obtained the same importance. Finally, non-subjectivity is satisfied by using dimensionless measures, which make exogenous normalization unnecessary.

Fifth condition: the multiplicative form of the exercise is based on cardinal numbers resulting in an ordinal kind of ranking.

The sixth condition is not fulfilled as only an illustration from a distant past was given. However, the full multiplicative form only uses a single method of multi-objective optimization. On the contrary, the multi-objective optimization by ratio analysis, MOORA, is more robust. Indeed, MOORA not only satisfies the first six conditions, but in addition, satisfies the seventh condition by using two different methods of multi-objective optimization. MOORA is the most robust method as no other method up till now exists satisfying the seven conditions better.

\section{The MOORA Method}

The method starts with a matrix of responses of all alternative solutions on all objectives:

$$
\boldsymbol{x}_{i j}
$$

with: $\boldsymbol{x}_{\boldsymbol{i} \boldsymbol{j}}$ as the response of alternative $j$ on objective $i$,

$\boldsymbol{i}=1,2, \ldots, \mathrm{n}$ as the objective,

$\boldsymbol{j}=1,2, \ldots, \mathrm{m}$ as the alternatives.

The MOORA method consists of two parts: the ratio system and the reference point approach.

We go for a ratio system in which each response of an alternative on an objective is compared to a denominator, which is representative for all alternatives concerning that objective (Brauers and Zavadskas 2006) prove that the most robust choice for this denominator is the square root of the sum of squares of each alternative per objective). 


$$
x_{i j}{ }^{*}=\frac{x_{i j}}{\sqrt{\sum_{j=1}^{m} x_{i j}^{2}}},
$$

with: $x_{i j}=$ response of alternative $j$ on objective $i$;

$j=1,2, \ldots, m ; m=$ the number of alternatives,

$i=1,2, \ldots n ; n=$ the number of objectives,

$x_{i j}{ }^{*}=$ a dimensionless number representing the normalized response of alternative $j$ on objective $i$.

For optimization, these responses are added in case of maximization and subtracted in case of minimization:

$$
y_{j}^{*}=\sum_{i=1}^{i=g} x_{i j}^{*}-\sum_{i=g+1}^{i=n} x_{i j}^{*}
$$

with: $i=1,2, \ldots, \mathrm{g}$ as the objectives to be maximized, $i=\mathrm{g}+1, \mathrm{~g}+2, \ldots, \mathrm{n}$ as the objectives to be minimized, $y_{j}{ }^{*}=$ the dimensionless response of alternative $\mathrm{j}$ with respect to all objectives. $y_{j}^{*}$ can be positive or negative depending on the totals of its maxima and minima. An ordinal ranking of the $y_{j}^{*}$ shows the final preference.

Reference Point Theory will go out from the ratios $x_{i j}{ }^{*}$ found in formula (4). In addition, one needs a Maximal Objective Reference Point. The Maximal Objective Reference Point is called realistic and non-subjective as the co-ordinates $\left(r_{i}\right)$, which are selected for the reference point, are realized as an optimum in one of the candidate alternatives. In this way arriving to:

$$
\left(r_{i}-x_{i j}^{*}\right)
$$

with: $i=1,2, \ldots, \mathrm{n}$ as the objectives, $j=1,2, \ldots$, $\mathrm{m}$ as the alternatives, $r_{i}=$ the $\mathrm{i}^{\text {th }}$ co-ordinate of the reference point, $x_{i j}{ }^{*}=$ the normalized response of alternative $\mathrm{j}$ on objective $\mathrm{i}$ as found in formula (4).

This matrix is subject to the Min-Max Metric of Tchebycheff (Karlin and Studden 1966: 279-280). Brauers (2008b: 98-103) proved that the Min-Max metric is the most robust choice between all the possible metrics of reference point theory.

$$
\underset{(j)}{\operatorname{Min}}\left(\max _{(i)}\left|r_{i}-x_{i j}^{*}\right|\right)
$$


$\left|r_{i}-x_{i j}^{*}\right|$ means the absolute value, necessary if $x_{i j}^{*}$ is larger than $r_{i}$ for instance by minimization.

In order to give more importance to an objective versus the other objectives its dimensionless number per alternative could be multiplied with a Significance Coefficient. The Attribution of Sub-Objectives represents another solution (Brauers 2002: 338).

\section{The MOORA Method and the Economy of the Belgian Regions}

Table 4 showed a ranking of the scenarios in its Full Multiplicative Form for Year Zero. Annex A demonstrates the MOORA method for the Belgian Regions in Year Zero. The conditions of robustness in Multi-Objective Methods dictate the use of the last available data as a base. However, a chain is only as strong as its weakest link. Also for MOORA the data for transfer payments between the Belgian Regions are only available until 2005 and in this way limiting the application until 2005. In addition, the Full Multiplicative Form was not repeated for 2005 due to the number of multiplications to be made. Table 5 applies MOORA for the Belgian Regions in 2005.

Table 5. MOORA applied on 7 objectives for the Belgian regions (year 2005): Ratio System Part (5a until 5c) and Reference Point Approach (5d-5e)

5a. Matrix of Responses of Alternatives on Objectives: $\left(x_{i j}\right)$

\begin{tabular}{l|c|c|c|c|c|c|c}
\hline & 1 & 2 & 3 & 4 & 5 & 6 & 7 \\
\hline & $\begin{array}{c}\text { Wallonia } \\
\text { Y/hposable } €\end{array}$ & $\begin{array}{c}\text { Brussels } \\
\text { Disposable } \\
\text { Y /head } €\end{array}$ & $\begin{array}{c}\text { Flanders } \\
\text { Disposable } \\
\text { Y/head } €\end{array}$ & $\begin{array}{c}\text { Transfer } \\
\text { from } \\
\text { Flanders } \\
(€ \text { bln) }\end{array}$ & $\begin{array}{c}\text { Flanders } \\
\text { Public } \\
\text { Debt } \\
\text { off } \\
\text { GRP }\end{array}$ & $\begin{array}{c}\text { Wallonia. } \\
\text { Public } \\
\text { Debt } \\
\text { of GRP }\end{array}$ & $\begin{array}{c}\text { Brussels } \\
\text { Public } \\
\text { Debt } \\
\% \text { GRP }\end{array}$ \\
\hline Scenario 0 & 14441.8 & 15096.1 & 16842.5 & 5.84 & 91.5 & 91.5 & 91.5 \\
\hline Scenario 1 & 15894 & 15894 & 15894 & 11.61 & 91.5 & 91.5 & 91.5 \\
\hline Scenario 2 & 13550.3 & 15096.1 & 16842.5 & 2.92 & 91.5 & 91.5 & 91.5 \\
\hline Scenario 3 & 14385.48 & 15103.71 & 16873.2 & 5.84 & 87.16 & 100.78 & 90.3 \\
\hline Scenario 4 & 14385.48 & 15103.71 & 16873.2 & 2.92 & 87.16 & 100.78 & 90.3 \\
\hline Scenario 5 & 15894 & 15894 & 15894 & 11.22 & 87.16 & 100.78 & 90.3 \\
\hline Scenario 6 & 14441.8 & 15096.1 & 16842.5 & 5.84 & 87.16 & 100.78 & 90.3 \\
\hline Scenario 7 & 12658.8 & 15307.1 & 17809.5 & 0 & 91.5 & 91.5 & 91.5 \\
\hline Scenario 8 & 12602.48 & 15314.71 & 17840.2 & 0 & 87.16 & 100.78 & 90.3 \\
\hline Scenario 9 & 17809.5 & 17809.5 & 17809.5 & 0 & 91.5 & 91.5 & 91.5 \\
\hline Scenario 10 & 17840.2 & 17840.2 & 17840.2 & 0 & 87.16 & 100.78 & 90.3 \\
\hline
\end{tabular}


5b. Sum of squares and their square roots

\begin{tabular}{l|l|l|l|l|l|l|l}
\hline Scenario 0 & 208565587 & 227892235 & 2836698 & 34.1056 & 8372.25 & 8372.25 & 8372.25 \\
\hline Scenario 1 & 252619236 & 252619236 & 2526192 & 134.792 & 8372.25 & 8372.25 & 8372.25 \\
\hline Scenario 2 & 183610630 & 227892235 & 2836698 & 8.5264 & 8372.25 & 8372.25 & 8372.25 \\
\hline Scenario 3 & 206942035 & 228122056 & 2847049 & 34.1056 & 7596.8656 & 10156.608 & 8154.09 \\
\hline Scenario 4 & 206942035 & 228122056 & 2847049 & 8.5264 & 7596.8656 & 10156.608 & 8154.09 \\
\hline Scenario 5 & 252619236 & 252619236 & 2526192 & 125.888 & 7596.8656 & 10156.608 & 8154.09 \\
\hline Scenario 6 & 208565587 & 227892235 & 2836698 & 34.1056 & 7596.8656 & 10156.608 & 8154.09 \\
\hline Scenario 7 & 160245217 & 234307310 & 3171783 & 0 & 8372.25 & 8372.25 & 8372.25 \\
\hline Scenario 8 & 158822502 & 234540342 & 3182727 & 0 & 7596.8656 & 10156.608 & 8154.09 \\
\hline Scenario 9 & 317178290 & 317178290 & 3171783 & 0 & 8372.25 & 8372.25 & 8372.25 \\
\hline Scenario 10 & 318272736 & 318272736 & 3182727 & 0 & 7596.8656 & 10156.608 & 8154.09 \\
\hline$\Sigma$ & 2474383092 & 2749457968 & 3196559 & 380 & 87442.44 & 102800.90 & 90785.79 \\
\hline root & 49743.1713 & 52435.2741 & 56538.1261 & 19.494874 & 295.70669 & 320.6258 & 301.30680 \\
\hline
\end{tabular}

5c. Objectives divided by their square roots and MOORA

\begin{tabular}{l|l|l|l|l|l|l|l|l|l}
\hline Scenario 0 & 0.2903273 & 0.2878997 & 0.29789633 & 0.2995659 & 0.309 & 0.285 & 0.30368 & -0.322 & $\mathbf{7}$ \\
\hline Scenario 1 & 0.3195212 & 0.3031166 & 0.28112004 & 0.5955419 & 0.3094282 & 0.2853794 & 0.30368 & -0.590 & $\mathbf{1 1}$ \\
\hline Scenario 2 & 0.2724052 & 0.2878997 & 0.29789635 & 0.149783 & 0.3094282 & 0.2853794 & 0.30368 & -0.190 & $\mathbf{6}$ \\
\hline Scenario 3 & 0.2891951 & 0.2880448 & 0.29843932 & 0.2995659 & 0.2947515 & 0.3143228 & 0.29969 & -0.333 & $\mathbf{9}$ \\
\hline Scenario 4 & 0.2891951 & 0.2880448 & 0.29843932 & 0.149783 & 0.2947515 & 0.3143228 & 0.29969 & -0.183 & $\mathbf{5}$ \\
\hline Scenario 5 & 0.3195212 & 0.3031166 & 0.28112004 & 0.5755359 & 0.2947515 & 0.3143228 & 0.29969 & -0.581 & $\mathbf{1 0}$ \\
\hline Scenario 6 & 0.2903273 & 0.2878997 & 0.29789633 & 0.2995659 & 0.2947515 & 0.3143228 & 0.29969 & -0.332 & $\mathbf{8}$ \\
\hline Scenario 7 & 0.2544832 & 0.2919237 & 0.31499983 & 0 & 0.3094282 & 0.2853794 & 0.30368 & -0.037 & $\mathbf{3}$ \\
\hline Scenario 8 & 0.253351 & 0.2920689 & 0.31554283 & 0 & 0.2947515 & 0.3143228 & 0.29969 & -0.048 & $\mathbf{4}$ \\
\hline Scenario 9 & 0.3580290 & 0.3396473 & 0.31499983 & 0 & 0.3094282 & 0.2853794 & 0.30368 & 0.114 & $\mathbf{1}$ \\
\hline Scenario 10 & 0.3586462 & 0.3402328 & 0.31554283 & 0 & 0.2947515 & 0.3143228 & 0.29969 & 0.106 & $\mathbf{2}$ \\
\hline
\end{tabular}

5d. Reference Point Theory with Ratios: co-ordinates of the reference point equal to the maximal objective values

\begin{tabular}{l|l|l|l|l|l|l|l|l|l|l|l}
\hline \multicolumn{1}{c|}{$\mathrm{r}_{\mathrm{i}}$} & 0.35864621 & 0.3402328 & 0.31554283 & 0.0000 & 0.2947515 & 0.2853794 & 0.299695 \\
\hline \multicolumn{7}{c}{ 5e. Reference Point Theory: Deviations from the reference point } & \multicolumn{3}{c}{$\begin{array}{c}\text { rank } \\
\text { min }\end{array}$} \\
\hline Scenario 0 & 0.0683189 & 0.052 & 0.0176 & 0.2996 & 0.014677 & 0.0000 & 0.00398 & 0.29957 & 7 \\
\hline Scenario 1 & 0.039125 & 0.03711624 & 0.03442279 & 0.5955 & 0.014677 & 0.0000 & 0.003982 & 0.59554 & $\mathbf{1 1}$ \\
\hline Scenario 2 & 0.086241 & 0.05233309 & 0.0176465 & 0.1498 & 0.014677 & 0.0000 & 0.00398 & 0.14978 & $\mathbf{5}$ \\
\hline Scenario 3 & 0.0694511 & 0.05218796 & 0.01710350 & 0.2996 & 0.000 & 0.0289 & 0 & 0.29957 & 7 \\
\hline Scenario 4 & 0.0694511 & 0.05218796 & 0.01710350 & 0.14978 & 0.0000 & 0.0289 & 0 & 0.14978 & $\mathbf{5}$ \\
\hline Scenario 5 & 0.039125 & 0.037 & 0.034 & 0.5755 & 0.0000 & 0.0289 & 0 & 0.57553 & $\mathbf{1 0}$ \\
\hline Scenario 6 & 0.0683189 & 0.05233309 & 0.0176465 & 0.2996 & 0.0000 & 0.0289 & 0 & 0.29956 & $\mathbf{7}$ \\
\hline Scenario 7 & 0.1041630 & 0.04830908 & 0.000543 & 0 & 0.014677 & 0.0000 & 0.00398 & 0.10416 & $\mathbf{3}$ \\
\hline Scenario 8 & 0.1052953 & 0.04816395 & 0 & 0 & 0 & 0.028943 & 0 & 0.10530 & $\mathbf{4}$ \\
\hline Scenario 9 & 0.0006172 & 0.00058548 & 0 & 0 & 0 & 0 & 0.000000 & 0.00398 & 0.01468 & $\mathbf{1}$ \\
\hline Scenario 10 & 0 & 0 & 0 & 0 & 0.028943 & 0 & 0.02894 & $\mathbf{2}$ \\
\hline
\end{tabular}


Sources

The basis is formed by scenarios 0 (the status quo) and 9 and 10 .

Scenario 0: Disposable Incomes: National Bank, Statistical Publications, actual Regional Accounts, 137.

Transfer Payments, see Table 1.

Public Debt: Table 2.

Scenario 9: disposable income of Flanders identical for Wallonia and Brussels: $16842.5 €+$ transfer payments provided per head $967 €=17809.5 €$ (transfer payments Flanders per head: Dury et al. (2008: 113).

Scenario 10: as sc.9 plus interest on revision part of public debt not realized immediately à 4.2\% (Documentatieblad, I, 2007: 54): 17809.5+ 30.7€=17840.2€.

Scenario 2: due to recession and huge inflation Flanders to maintain its income per person reduces its transfer payments to the half; for Wallonia a loss of $891.5 €$ per head (Dury et al. 2008: 113).

Scenario 3: Maastricht $122.2 \%$ of GDP meant for Wallonia $134.6 \%$ of its GRP Flanders $116.4 \%$ of its GRP

Brussels $120.6 \%$ of its GRP

On the $200591.5 \%$ of GDP: $\rightarrow$

Wallonia $100.8 \%$ of its GRP

Flanders $87.2 \%$ of its GRP

Brussels $90.3 \%$ of its GRP

Flanders: $16842.5+$ interest $30.7=16873.2 €$

Wallonia: 14441.8 minus interest to be paid $56.32 €=14385.48 €$

Brussels:15096.1 $-7.61 €=15103.71 €$

Scenario 4: Scenario $2+$ Scenario 3

Scenario 1: average Belgian, equalization by going down for Flanders

Scenario 5: Scenario 1+ plus more or less Scenario 3

Scenario 6: as Scenario 0 but now with the redistribution of the public debt

Scenario 7: no transfer payments but solidarity in the national debt: profit for Flanders and Brussels loss for Wallonia (Dury et al. 2008: 113):

Flanders $16842.5+967=17809.5 €$

Wallonia $14441.8-1783=12658.8 €$

Brussels $15096.1+211=15307.1 €$

Scenario 8: Scenario $7+$ Scenario 3.

\section{MULTIMOORA as a combination of the Full Multiplicative Form and of MOORA}

Following Table 6 shows a combination of the Full Multiplicative Form and of MOORA under the name of MULTIMOORA. If the first 6 conditions of robustness are fulfilled as much as possible MULTIMOORA becomes the most robust approach existing up till now. 
Table 6. Ranking the Belgian Regions by MULTIMOORA

\begin{tabular}{|c|c|c|c|c|c|c|}
\hline Scenarios & $\begin{array}{c}\text { Full } \\
\text { Multiplicative } \\
\text { Form } \\
\text { Year Zero }\end{array}$ & $\begin{array}{c}\text { MOORA } \\
\text { Ratio } \\
\text { System } \\
\text { Year Zero }\end{array}$ & $\begin{array}{l}\text { MOORA } \\
\text { Reference } \\
\text { Point } \\
\text { Year Zero }\end{array}$ & $\begin{array}{c}\text { MULTIMOORA } \\
\text { Year Zero }\end{array}$ & $\begin{array}{l}\text { MOORA } \\
\text { Ratio } \\
\text { System } \\
2005\end{array}$ & $\begin{array}{c}\text { MOORA } \\
\text { Reference } \\
\text { Point } \\
2005\end{array}$ \\
\hline Scenario IX & 1 & 1 & 1 & 1 & 1 & 1 \\
\hline Scenario X & 2 & 2 & 2 & 2 & 2 & 2 \\
\hline Scenario VII & 3 & 3 & 3 & 3 & 3 & 3 \\
\hline Scenario VIII & 4 & 4 & 3 & 4 & 4 & 4 \\
\hline Scenario II & 5 & 5 & 5 & 5 & 6 & 6 \\
\hline Scenario IV & 6 & 6 & 5 & 6 & 5 & 5 \\
\hline Scenario III & 7 & 7 & 7 & 7 & 9 & 7 \\
\hline Scenario I & 8 & 8 & 8 & 8 & 11 & 11 \\
\hline Scenario V & 9 & 9 & 8 & 9 & 10 & 10 \\
\hline Scenario $\mathrm{O}$ & 10 & 10 & 10 & 10 & 7 & 7 \\
\hline Scenario VI & 11 & 11 & 10 & 11 & 7 & 7 \\
\hline
\end{tabular}

One may say that all rankings are compatible until Scenario III. Consequently the first seven rankings will be discussed.

\subsection{Geographical Transfer Payments on discussion worldwide}

The first four rankings are characterized by the absence of transfer payments and the following three by the diminishing of transfer payments. Transfer payments are quite common in daily life such as in all kinds of insurances, but transfer payments which are considered here are geographical, automatic and structural ones.

First of all geographical transfer payments can be automatic through fiscal or para-fiscal channels such as social security. They are also structural and not cyclical as they are maintained under all circumstances and form an essential and enduring financial instrument for a state or a region. This kind of transfer payments is very much contested not only in Belgium but also by the richer regions in Germany and Italy. In Belgium it caused even an Income Paradox at least until 1996: by the transfer payments the richer Flemish inhabitants came off worst compared to the other Belgians (table 7).

One could argue that in Table 5 and in Appendix A transfer payments are overestimated by giving them the same importance as private income and public debt. This is not true as three objectives concern private income and three public debts against only one objective for transfer payments. More importance could even be given to private income and public debt. Wallonia would not like to give more importance to public debt due to the unfavourable position of Wallonia towards public debt. Nevertheless by giving a significance coefficient of two to each of the private income objectives transfer payments keep their crucial position (see Appendix B). Indeed, the four scenarios with the negation of transfer payments remain first ranked.

Instead of geographical, automatic and structural transfer payments direct investments are to be preferred for reconversion of regions or for developing of countries. There- 
fore the so-called Marshall Plan is a good idea for Wallonia, but lesser means will be available as Wallonia from now on has to finance its social security by itself. However the possibility exists that Flemish firms will participate in the Marshall Plan. For developing countries the old slogan "No Aid but Trade" seems to be replaced by "No Aid but Investments", a device seemingly followed by the Chinese in Africa. On the other side the objective-oriented investments of the international organizations are not always very successful. Pre-set filters such as a minimum of $12 \%$ I.R.R is a disaster for the country in question ${ }^{4}$. Also Cost-Benefit Analysis is not very effective for the following reasons:

1) Cost-Benefit Analysis usually concerns a single project but theoretically one could compare the balance of costs and benefits for different projects;

2) Cost-Benefit can be immoral, for instance if unemployment is only measured by the obtained unemployment allowances notwithstanding the moral attitude of the unemployed.

3) Translation into money terms is not always very successful if the objectives are expressed in different units. It is true that private income and transfer payments are already expressed in money terms but the $€$ has not always the same meaning: the $€$ in private income is not the same as the $€$ in transfer payments. After the terminology (see paragraph 7 above) a $€$ can move from Private Income to transfer payments but a $€$ can not move from transfer payments to private income. Generally units of objectives are not transferable into money units.

For all these shortcomings, investments in regions in reconversion or in developing countries can better be analyzed by multiple objectives keeping their own units.

\subsection{Discussion of the Ranking of the Scenarios for an Optimal Belgian Policy}

\subsubsection{Scenarios IX and $X$ first ranked}

In both Scenarios Wallonia and Brussels come at the economic level of Flanders, even without transfer payments coming from Flanders, whereas the economic growth rate of Flanders is maintained. In addition in Scenario X Wallonia even agrees on the partition of the National Public Debt unfavourable for Wallonia.

I) The outcome is a Win-Win operation for all parties concerned if Flanders keeps a high growth rate. However, these scenarios have no economic foundation, notwithstanding the so-called Marshall Plan of economic development for Wallonia. We note for instance for Wallonia:

- level of work participation (age 15-64): 57.2\% $\rightarrow$ Lisbon target: 70\% [FOD Economy];

- level of work participation, women: $50.4 \% \rightarrow$ Lisbon target: $60 \%$ [FOD Economy];

- level of work participation (age 55-64): 33.6\% $\rightarrow$ Lisbon target: 50\% [FOD Economy];

- unemployment: $10.1 \%$ of the professional population [FOD Economy 2008,] but actually at $16 \%$;

${ }^{4}$ Let us remember that the Internal Rate of Return (I.I.R) means the interest rate against which the discounted cash flow equals the investment over the foreseen lifetime of the project. 
- $45 \%$ of the working population works in government service or in non-profit organizations (Forem 2009);

- $1.21 \%$ of the Walloon territory is only occupied by firms (E. Domb previously president of the Walloon Employers Association);

- "Walloons have no economic culture" (E. Domb, De Tijd 12/1/2010);

- Wallonia's main industry, the steel industry, is in decay. Some positive developments have to be mentioned such as the growth of Charleroi airport as the second airport of Belgium and the flourishing science parks of Louvain-la-Neuve and Sart-Tilman.

Capital Brussels is also far away from the Flemish level:

- level of work participation (age 15-64): 55.6\% $\rightarrow$ Lisbon target: 70\% [FOD Economy];

- level of work participation, women: $48.4 \% \rightarrow$ Lisbon target: $60 \%$ [FOD Economy];

- level of work participation (age 55-64): 39.7\% $\rightarrow$ Lisbon target: 50\% [FOD Economy];

- unemployment: $16 \%$ of the professional population [FOD Economy, 2008] but actually at $25 \%$;

- the economy of Brussels is in decay:

1) Brussels as international financial center: all banks are in foreign hands. The Brussels Stock Exchange is replaced by the international Euronext.

2) Brussels was the decision center for the Belgian energy sector, the mining industry, the metal and steel industry: all mines were closed and the energy, metal and steel sectors came in foreign hands.

3) Some productions disappeared such as tobacco products. Other sectors remain important but are mostly depending on the overall activity in the whole of Belgium (measured in Gross Value Added for 2007 and compared with the national figures, Belgostat):

Electricity and gas distribution $31.52 \%$,

Services: hotels and restaurants $22.68 \%$,

Transport 13.1\%,

Support of transport and travel agencies: $18.71 \%$,

Post and telecommunications: $45.53 \%$,

Commerce and exploitation of real estate: $14.6 \%$,

Computers: $29.76 \%$,

Business services: $16.36 \%$.

Flanders

- level of work participation (age 15-64): 66.5\% $\rightarrow$ Lisbon target: 70\% [FOD Economy];

- level of work participation, women: $60.8 \% \rightarrow$ Lisbon target: $60 \%$ [FOD Economy];

- level of work participation (age 55-64): 34.3\% $\rightarrow$ Lisbon target: 50\% [FOD Economy];

- unemployment: $3.9 \%$ of the professional population [FOD Economy 2008] but actually at 7\%; in fact overevaluated as in Belgium there is no time limit on unemployment allowances;

- The economy of Flanders:

1) The chemical industry around Antwerp is the second in the world after Houston (Texas).

2) The sea port of Antwerp is the second in Europe after Rotterdam. 
3) The Gas terminal in Zeebrugge in one of the biggest in the world.

4) Antwerp is the first trading center for diamonds in the world.

5) The Flemish textile industry is famous for carpets and other refined products.

Scenario 8 (Table 5) gives the most realistic situation for Wallonia with a disposable income per head of $12602.48 €$, but without the benefit of incoming transfer payments. With the ideal situation of scenario $10(17840.2 €)$ Wallonia falls short of $41.56 \%$, a situation never to be reached even with Chinese growth rates, certainly when Flanders continues with an average growth rate of at least $1.5 \%$. In addition, in scenario 10 a public debt has to be covered of $100.78 \%$ of its GRP (in the Maastricht norm even of $134.6 \%$ ).

A similar situation occurs for Brussels. Scenario 7 gives the most plausible situation for Brussels at $15307.1 €$ against the ideal situation of $17840.2 €$ in scenario 10 . The difference measures a shortage of $16.55 \%$. In addition after the 2005 figures a public debt has to be covered of $90.3 \%$ of its GRP (in the Maastricht time it was even 120.6\%).

II) Conclusion: Scenarios 9 and 10 are entirely unrealistic and have not to be taken into consideration. One could argue that they have not to be included as scenarios but rather withered away in a preliminary filtering process, which would exclude impossible situations. Nevertheless this way of thinking is false. By including them in the aggregation process, the rights of the less favoured regions are better taken into account.

\subsubsection{Third Ranked but in fact First Ranked: Scenario VII, the Scenario of Solidarity only for the Partition of the National Public Debt}

The transfer payments disappear but solidarity remains for the National Public Debt. In order to have control on the transfer payments the entire tax system has to move to the regions and also all para-fiscal systems such as the social security allowances. The regions could for example redistribute indirect taxation to the European Union if the European Union would use the manipulation of indirect taxation as an instrument of its economic policy.

Under these circumstances Belgium moves from a federal state to a confederation of states, but not to secession as Flanders shows the goodwill to maintain the status quo for the public debt. Indeed, expressed in time zero (the Maastricht norm) the repartition of the Public debt is as follows:

- Wallonia $122.2 \%$ of its GRP, much less than the mentioned $134.6 \%$ of its GRP,

- Flanders $122.2 \%$ of its GRP,

- Brussels $122.2 \%$ of its GRP.

\subsubsection{Fourth Ranked but in fact Second Ranked: Scenario VIII, no Solidarity at all}

This scenario means that the tax system is entirely regional and also all para-fiscal systems such as the social security allowances. The transfer payments disappear and no solidarity remains for the National Public Debt. This scenario could mean a move either from a federal state to a confederation of states or to complete secession. 


\subsubsection{Fifth Ranked but in fact Third Ranked: Scenario II, the Scenario of an Unfavourable Growth Rate for Flanders}

Due to an unfavourable growth rate e.g. of $-3 \%$ and an inflation rate of $1 \%$ the crucial border line of 3.3\% is passed (Brauers 1999b: 8-9) and in order not to destabilize its own economy Flanders has to diminish considerably its transfer payments. Nevertheless, the solidarity in the national public debt is kept unchanged.

\subsubsection{Sixth Ranked but in fact Fourth Ranked: Scenario IV, the Scenario of an Unfavourable Growth Rate for Flanders with the decrease of its transfer payments and in addition its demand for a new repartition of the National Public Debt}

The situation is comparable with the previous scenario but in addition Flanders asks for a new repartition of the national public debt.

\subsubsection{Seventh Ranked but in fact Fifth Ranked: Scenario III, the Scenario in which Flanders asks for a Repartition of the National Public Debt}

Flanders not only contribute for transfer payments but also pays interest charges on a part of the national public debt for which it is not responsible. Therefore Flanders asks for a repartition of the national public debt. Automatically the transfer payments from Flanders diminish. Disagreement about the ranking of the following scenarios means that they are not taken into consideration.

\subsubsection{Not Useful Ranked but historically in fact interesting: Scenario I, the Scenario of the average Belgian and Scenario $V$ the average Belgian but with Flanders asking for a Repartition of the National Public Debt}

These scenarios where the most advanced region is punished as it is obliged to diminish its income in favour of the less advancing regions and in this way arriving at a national average has no chance at all in Belgium. Nevertheless, it was the policy in Belgium for a while. In a time of automatic and structural transfer payments "do not kill the goose that lays the golden eggs".

\section{An Optimum Economic Policy for Belgium}

From the MULTIMOORA application for Belgium the following conclusions can be drawn.

1) The scenario where the most advancing region has to decrease its disposable incomes to the level of the less advancing regions has no chance in the ranking of scenarios. Nevertheless it was the policy in Belgium for a while, creating even an Income Paradox (see Table 7). Flanders with the highest Gross Regional Product per head saw its Disposable Income per head decrease even lower than the national average. 
2) In connection with the previous point geographical transfer payments, which at the same time are automatic and structural, are economically not acceptable between regions. They result in stationary instead of progressive repercussions. Also elsewhere this statement, even for countries, is generally recognized.

3) Accepting the previous points means that for controlling the structural transfer payments each Belgian region needs its own taxation system and that also all

Table 7. Income Paradox in Belgium (1996)

\begin{tabular}{l|l|l}
\hline \multicolumn{1}{c|}{ in BEF* } & \multicolumn{1}{|c|}{$\begin{array}{c}\text { GRP } \\
\text { per head }\end{array}$} & \multicolumn{1}{|c}{$\begin{array}{c}\text { Disposable } \\
\text { Income per head }\end{array}$} \\
\hline Flanders & 869,976 & 676,743 \\
\hline Wallonia & 752,452 & 692,883 \\
\hline Brussels & 839,913 & 698,809 \\
\hline Belgium & 828,693 & 684,076 \\
\hline
\end{tabular}

*1 $€$ equaled $40.3399 \mathrm{BEF}$

Calculations in: W K. Brauers: het Bruto Regionale Product van Vlaanderen, Wallonië en Brussel, Working Paper 99/2, RUCA, Faculty of Applied Economics, University of Antwerp, 8-18.

para-fiscal aspects, including Social Security, are regionalized. In this way the comparative costs of each region come fully into effect. The Monetary and Economic Union of Belgium, is past history (Brauers et al. 1979: 47). Previously each Belgian region had a favourite position towards the other regions. The monetary policy was unified and the regions reacted in the same way to inflation, deflation or devaluation, whereas the monetary policy was based on a common agreement between all Belgians. The European Monetary Union brings the monetary decisions much farther away from the Belgian regions. A mutual favourite position for the Belgian regions in economic matters is also no more possible inside the European Economic Union. Instead, a confederation of Belgian states is born for economic matters.

4) The confederation of Belgian states for economic matters is politically supported by the Belgian Constitution (1994) in its article 35 which says: "the Regions are entitled to all matters which are not allotted to the federal government by law".

5) Flanders remains attached to the confederation if it shows goodwill by not asking a redistribution of its share in the public national debt.

6) If Flanders asks also the redistribution of its share in the public national debt the following questions remain:

- which method is used to allocate each share per region in the national public debt?

- once the national public debt is redistributed, does Flanders prefer confederation or secession?

7) The most plausible scenarios namely scenario 7 and even more scenario 8 show the real economic situation of Wallonia. They mean a Win-Loss relation between 
Flanders and Wallonia. For Wallonia it signifies a lesson of total reconversion of its economic policy and a necessary mobilization of all its capabilities.

\section{Conclusion}

The remark that significance of robustness depends on the context is specified in different ways. First, robustness can be considered either in a statistics-econometrics meaning or as qualitative robust. However, a move to a qualitative definition seems to join more and more the meaning of common language, like strong, stronger, strongest, translated as: the most robust one, more robust than..., as robust as....., robust, weak robust, less robust than..., not robust etc. Second, if robustness is indicated as vague or arbitrary perhaps it is also the case with inference statistics, probability theory and statistical specification.

Following conditions have to be satisfied for a robust method of multi-objective optimization:

1) the method of multiple objectives in which all stakeholders are involved is more robust than one in which only one decision maker or different decision makers defending only a limited number of objectives are involved. All stakeholders mean everybody interested in a certain issue and finally ending up with the consumer. Consequently, the method of multiple objectives which takes into consideration consumer sovereignty is more robust than this one which does not respect consumer sovereignty;

2) the method of multiple objectives in which all non-correlated objectives are considered is more robust than this one in which only a limited number of objectives is involved;

3) the method of multiple objectives in which all interrelations between objectives and alternatives are taken into consideration at the same time is more robust than this one in which the interrelations are only examined two by two;

4) the method of multiple objectives which is non-subjective is more robust than this one which uses subjective estimations for the choice and the importance of the objectives and for normalization. For instance, a method of multiple objectives which uses non-subjective dimensionless measures is more robust than this one which for normalization uses subjective weights or subjective non-additive scores like in the traditional Reference Point Theory;

5) the method of multiple objectives based on cardinal numbers is more robust than this one based on ordinal ones: an ordinal number is one that indicates order or position in a series, like first, second, etc.. The robustness of cardinal numbers is based on the saying of Arrow: "Obviously, a cardinal utility implies an ordinal preference but not vice versa" and also on the fact that adding, subtracting, multiplication and division are only reserved for cardinal numbers;

6) the method of multiple objectives which uses the last recent available data as a base in the response matrix is more robust than this one based on earlier data;

7) once the previous six conditions fulfilled the use of two different methods of 
multi-objective optimization is more robust than the use of a single method; the use of three methods is more robust than the use of two, etc.

As the need for external Normalization is not present, given the dimensionless measures, and if the choice and importance of the objectives is taken care of, eventually with the assistance of the Ameliorated Nominal Group and Delphi Techniques, the Multiplicative Form and the Multi-Objective Optimization by Ratio Analysis Method (MOORA) satisfy the first six conditions. In addition, if we join together the Multiplicative Form (one method) and MOORA two methods) we get the most robust construction with the use of three different methods (MULTIMOORA).

Does the test with MULTIMOORA on the economy of the Belgian Regions satisfy the seven conditions of robustness? Concerning the first condition, the stakeholders were substituted by the researchers of the study. Consumer sovereignty was considered not only by the private income per head in the three regions but even much more by the disposable income after taking into account the transfer payments between the regions.

The second condition is fulfilled as only non-correlated objectives are considered. Third, all interrelations between objectives and alternatives are taken into consideration at the same time.

Fourth, non-subjectivity is satisfied by using non-subjective dimensionless measures, which makes further normalization unnecessary. The choice of the objectives gives the impression of completeness. In principle no objective receives more importance than the others by the introduction of a significance coefficient or of different sub-objectives. Nevertheless, one could argue that transfer payments are overestimated by giving them the same importance as disposable income and public debt. This is not true as three objectives concern disposable income and three others the public debt against only one objective for transfer payments. More importance could even be given to disposable income and public debt. Wallonia would not like to give more importance to public debt due to the unfavourable position of Wallonia towards public debt. By giving a significance coefficient of two to each of the disposable income objectives the transfer payments kept their original crucial position (see therefore Appendix B).

Fifth, the multiplicative form and MOORA are based on cardinal numbers. Sixth, this method uses the last recent available data. However, as many different data are needed not always from the same time period, like a chain having the value of the weakest link, 2005 had to be chosen as a base.

One could think of aggregating the Multiplicative Form and MOORA into one multiobjective system, called MULTIMOORA. In this way MULTIMOORA becomes the fulfillment of the seven robustness conditions on the basis of three different methods.

Maybe we are still far away of a closed system for Multi-Objective Optimization. Nevertheless, we tried with the available means at our disposition to come as nearby as possible to the seven conditions of robustness for multi-optimization, perhaps the road to an ideal closed system. 
From the MULTIMOORA application for Belgium the following conclusions could be drawn.

1) The scenario where the most advanced region has to diminish its income in favour of the less advancing regions has no chance at all. Nevertheless it was the policy in Belgium for a while creating even an Income Paradox: Flanders as the most advanced region saw its income per head falls even under the national average. In a time of automatic and structural transfer payments "do not kill the goose that lays the golden eggs".

2) Even a step further: geographical transfer payments, which are automatic and structural, are not acceptable between regions of a country. They result in immobility. The Belgian example illustrates this point of view. It is better to promote direct investments.

3) Accepting the previous point means that each region will have its own taxation system and that also all para-fiscal aspects, including Social Security, are regionalized. In this way the comparative costs of each region come fully into effect.

4) The best scenarios are those where the less advancing regions try to reach the higher level of the most advancing country, even without transfer payments in their favor. For Belgium these scenarios are completely unrealistic. Wallonia falls short of $41.56 \%$, a situation never to be reached even with Chinese growth rates, certainly when Flanders continues with an average growth rate of at least $1.5 \%$. In addition, Wallonia has to carry a national public debt of $100.78 \%$ of its Gross Regional Product (in the Maastricht norm even of 134.6\%).

A similar situation occurs for Brussels. The difference measures a shortage of $16.55 \%$. In addition Brussels has to cover a national public debt of $90.3 \%$ of its Gross Regional Product (in the Maastricht time it was even 120.6\%).

5) The second best scenarios for Belgium are economically confederative, without transfer payments, which are automatic and structural.

6) The confederation of Belgian states is politically supported by the Belgian Constitution (1994).

7) Flanders remains attached to the confederation if it shows goodwill by not asking a redistribution of its share in the public national debt.

8) If Flanders asks also for the redistribution of the public national debt the following questions remain:

- which method is used to allocate each share per region in the national public debt?

- if the national public debt is redistributed, does Flanders prefer confederation or secession? 


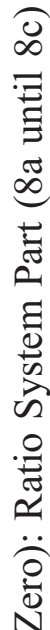

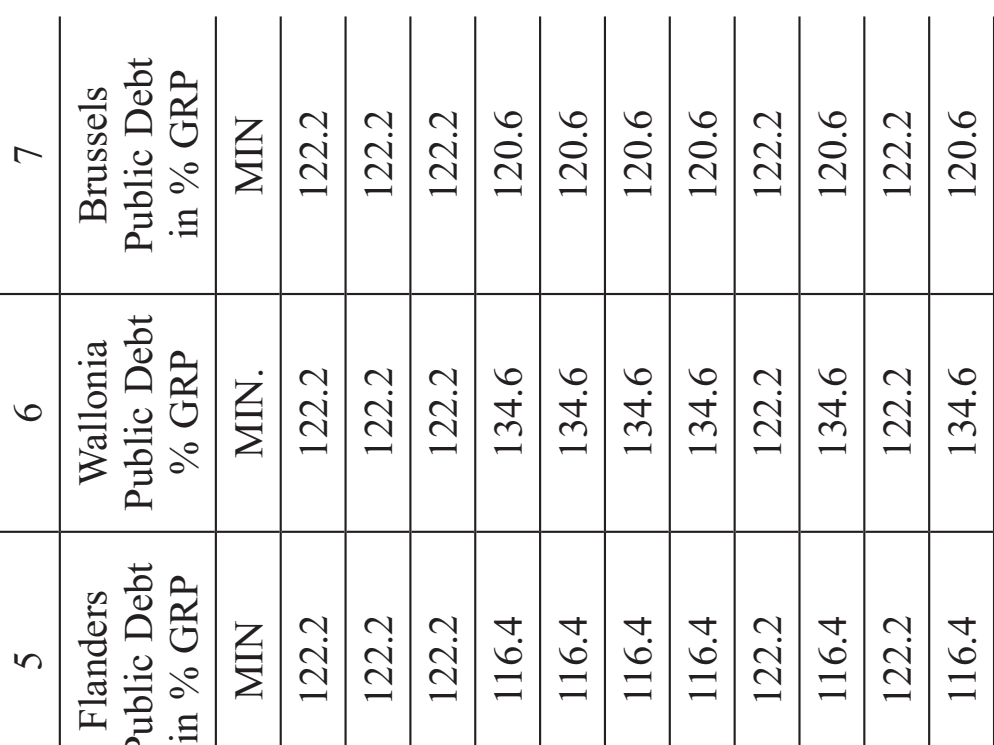

:

产

酷

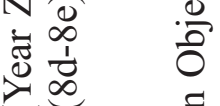

oี

응

का

音艺

a

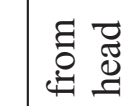

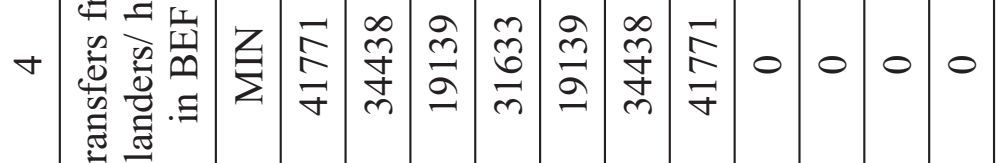

要

월

क्ष

is

.

F I

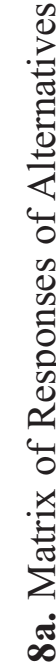

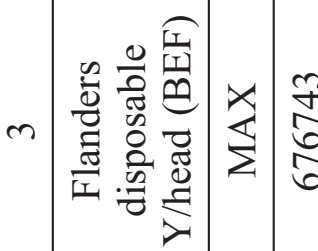

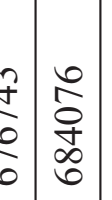

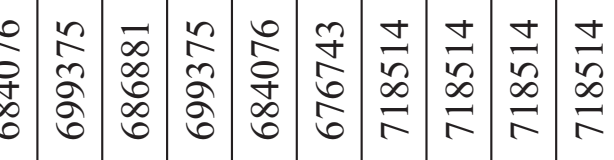

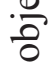

N

ธี

.

产

\)

蕓

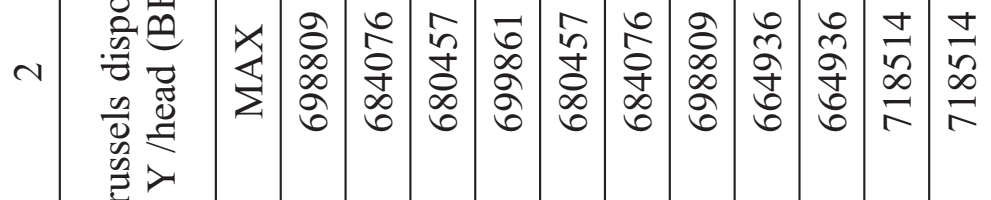

D

$\frac{0}{0}$

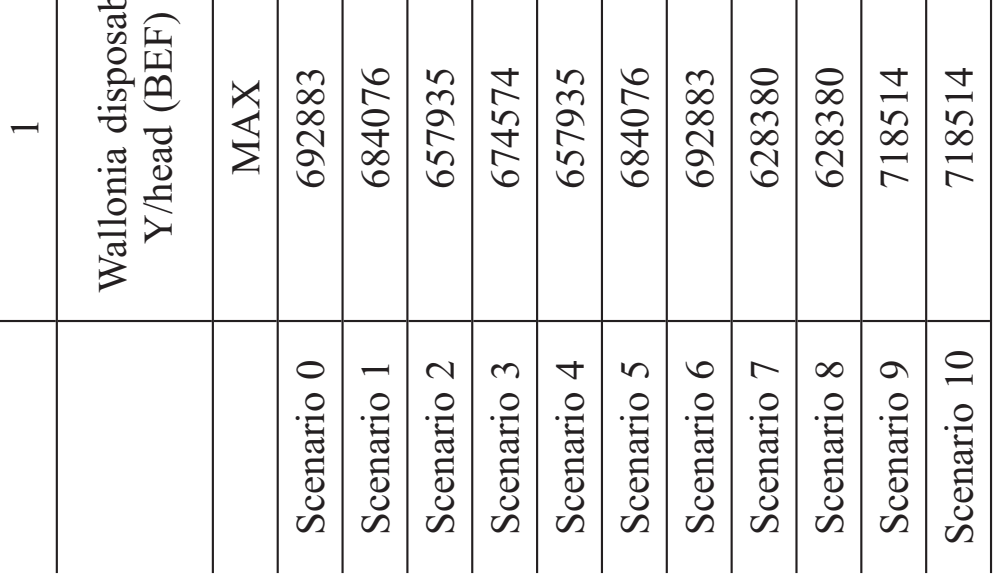




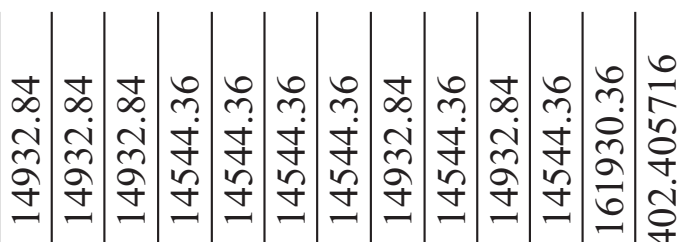

t

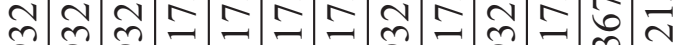
守

ఫ ர்

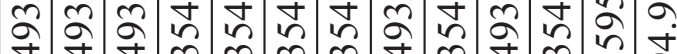

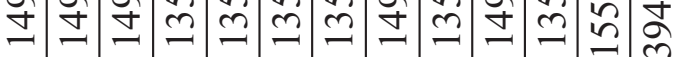

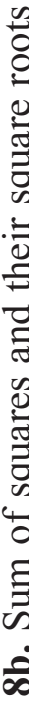

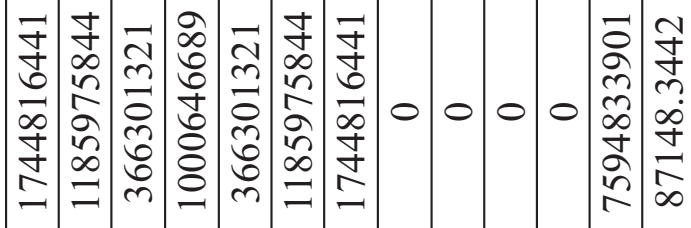

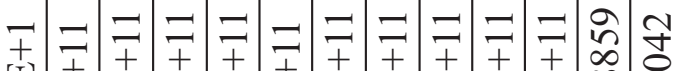

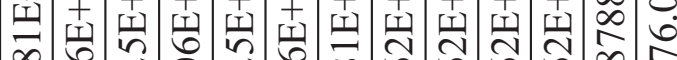
œ î.

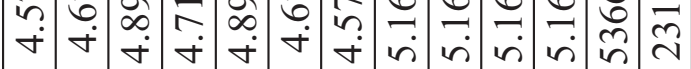

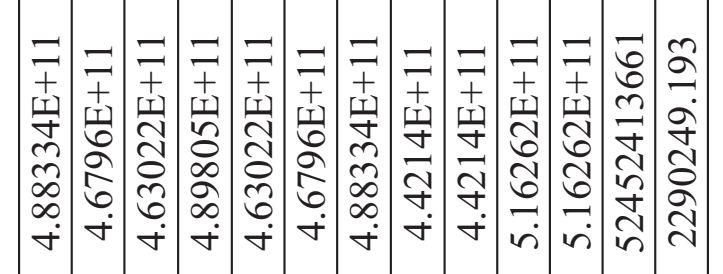

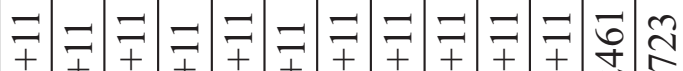

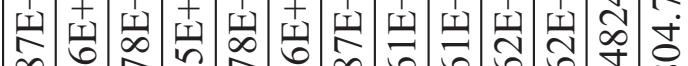

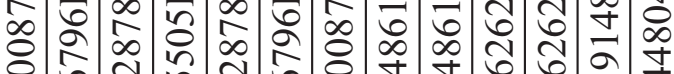
D

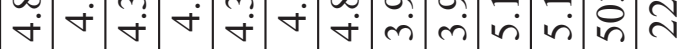

- $-2 m+\operatorname{mon} \infty$ a

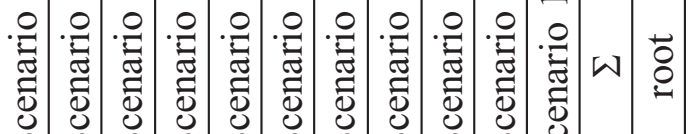

틀

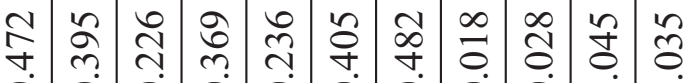

苯

$\begin{array}{llllllllllll} & 0 & 0 & 0 & 0 & 0 & 0 & 0 & 0 & 0 & 0 & 0 \\ 0 & 1 & 1 & 0 & 0 & 0\end{array}$

m

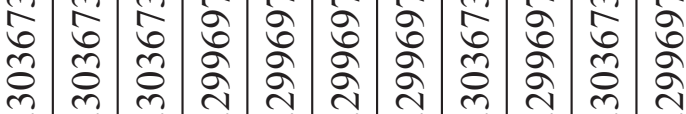

ல்

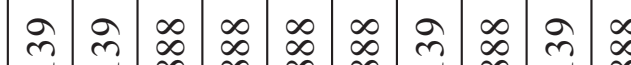

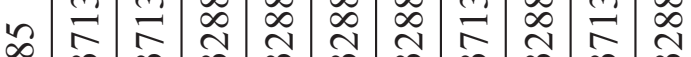

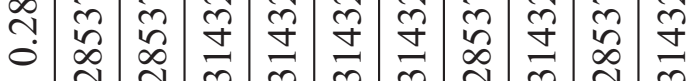

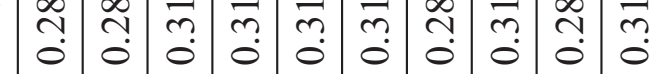

๖

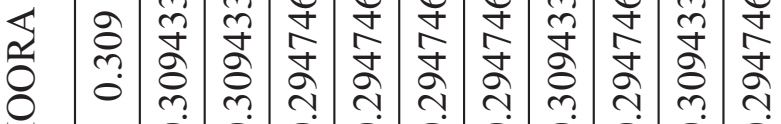

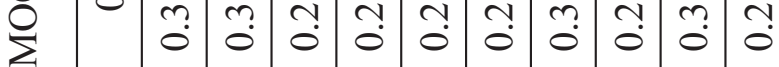

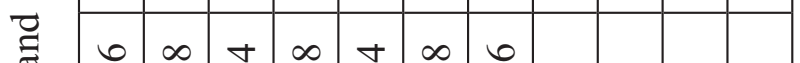

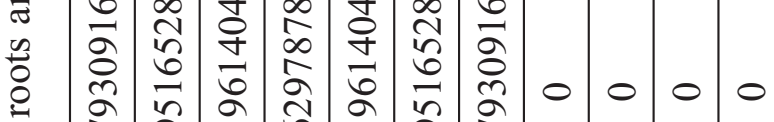

㫕

हु

当

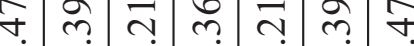

-

$\infty$ \&

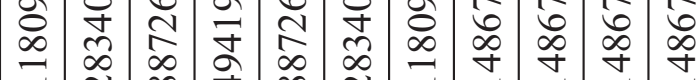

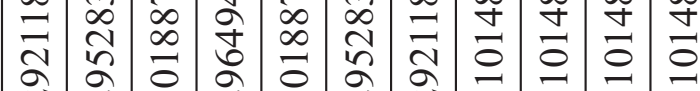

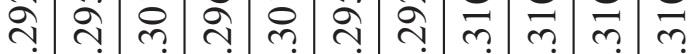

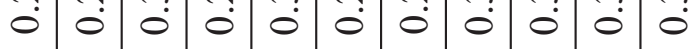

๑ ఫ オ

m

ปิ

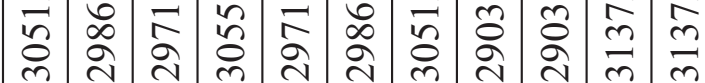

$\begin{array}{lllllllllll}0 & 0 & 0 & 0 & 0 & 0 & 0 & 0 & 0 & 0 & 0\end{array}$

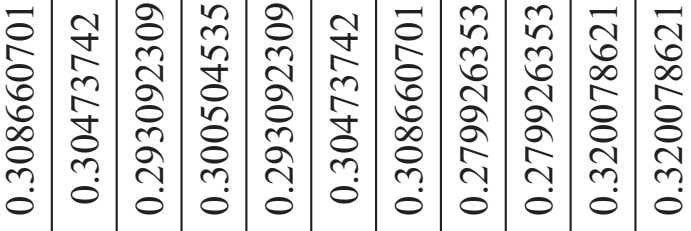

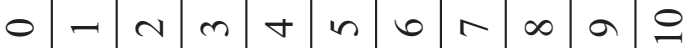

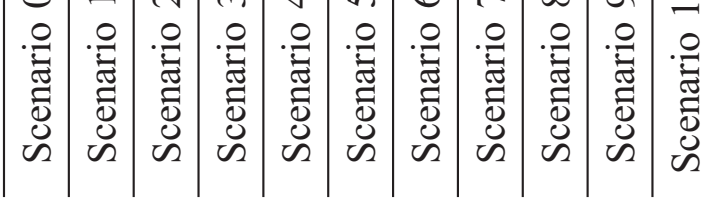


告)

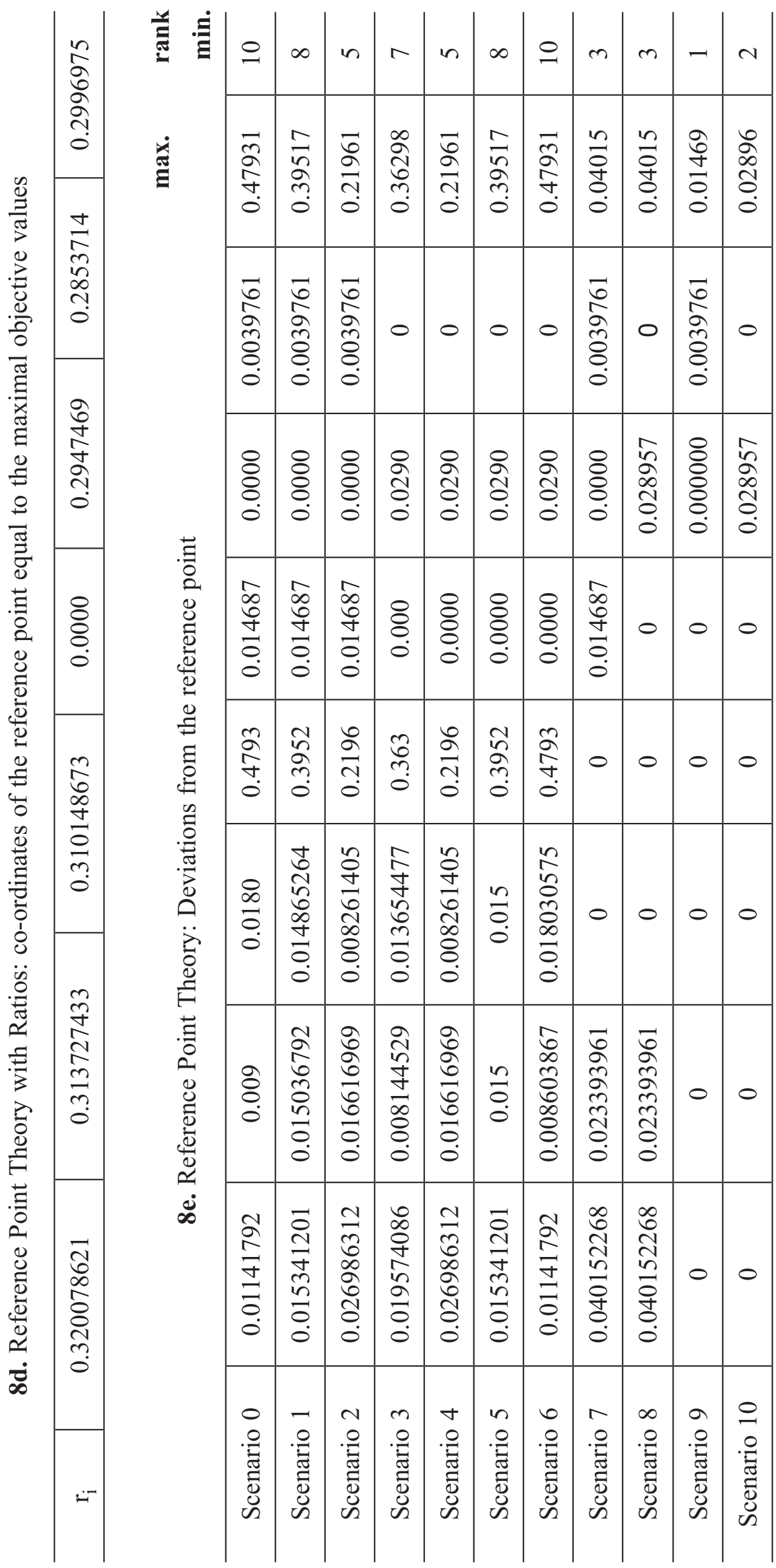




\section{Appendix B}

In Table 9 MOORA is applied on 7 objectives for the Belgian Regions with a significant coefficient of 2 for Private Income in the three Regions (year 2005).

The basis is Table 5c. Indeed Tables 9a and $9 \mathrm{~b}$ are successively equal to Tables 5a and 5 b. At that moment formula (4) is applied:

$$
x_{i j}^{*}=\frac{x_{i j}}{\sqrt{\sum_{j=1}^{m} x_{i j}^{2}}} .
$$

Table 9. Reference Point Part with a significance coefficient of 2 for the private incomes

9c. Objectives divided by their square roots $x_{i j}^{*}$ and MOORA

\begin{tabular}{|c|c|c|c|c|c|c|c|c|c|}
\hline & 1 & 2 & 3 & 4 & 5 & 6 & 7 & & \\
\hline & $\begin{array}{c}\text { Wallonia } \\
\text { disposable } \\
\text { Y/head }\end{array}$ & $\begin{array}{c}\text { Brussels } \\
\text { disposable } \\
\text { Y/head }\end{array}$ & $\begin{array}{c}\text { Flanders } \\
\text { disposable } \\
\text { Y/head }\end{array}$ & $\begin{array}{l}\text { Transfer } \\
\text { from } \\
\text { Flanders }\end{array}$ & $\begin{array}{c}\text { Flanders } \\
\text { Public } \\
\text { Debt }\end{array}$ & $\begin{array}{c}\text { Wallonia. } \\
\text { Public } \\
\text { Debt }\end{array}$ & $\begin{array}{c}\text { Brussels } \\
\text { Public } \\
\text { Debt }\end{array}$ & & \\
\hline & MAX & MAX & MAX & MIN & MIN & MIN & MIN & & \\
\hline & & & & & & & & sum & rank \\
\hline Scenario 0 & 0.29032729 & 0.28789971 & 0.29789633 & 0.2995659 & 0.309 & 0.285 & 0.3036772 & -0.322 & 7 \\
\hline Scenario 1 & 0.31952124 & 0.30311656 & 0.28112004 & 0.5955419 & 0.3094282 & 0.2853794 & 0.3036772 & 0.590 & 11 \\
\hline Scenario 2 & 0.27240523 & 0.28789971 & 0.29789635 & 0.149783 & 0.3094282 & 0.2853794 & 0.3036772 & 0.190 & 6 \\
\hline Scenario 3 & 0.28919507 & 0.28804484 & 0.29843932 & 0.2995659 & 0.2947515 & 0.3143228 & 0.2996945 & 0.333 & 9 \\
\hline Scenario 4 & 0.28919507 & 0.28804484 & 0.29843932 & 0.149783 & 0.2947515 & 0.3143228 & 0.2996945 & 0.183 & 5 \\
\hline Scenario 5 & 0.31952124 & 0.30311657 & 0.28112004 & 0.5755359 & 0.2947515 & 0.3143228 & 0.2996945 & 0.581 & 10 \\
\hline Scenario 6 & 0.29032729 & 0.28789971 & 0.29789633 & 0.2995659 & 0.2947515 & 0.3143228 & 0.2996945 & 0.332 & 8 \\
\hline Scenario 7 & 0.25448317 & 0.29192372 & 0.31499983 & 0 & 0.3094282 & 0.2853794 & 0.3036772 & 0.037 & 3 \\
\hline Scenario 8 & 0.25335096 & 0.29206885 & 0.31554283 & 0 & 0.2947515 & 0.3143228 & 0.2996945 & 0.048 & 4 \\
\hline Scenario 9 & 0.35802904 & 0.33964731 & 0.31499983 & 0 & 0.3094282 & 0.2853794 & 0.3036772 & 0.114 & 1 \\
\hline Scenario 10 & 0.35864621 & 0.34023279 & 0.31554283 & 0 & 0.2947515 & 0.3143228 & 0.2996945 & 0.106 & 2 \\
\hline
\end{tabular}

All figures of columns 1, 2 and 3 of the private incomes of Wallonia, Brussels and Flanders are multiplied by 2. For instance, private income of Wallonia in scenario 0 becomes: $0.29032729 * 2=0.5806545$.

9c (bis.) Objectives divided by their square roots $x_{i j}^{*}$ but with the private incomes multiplied by 2 and MOORA

\begin{tabular}{|l|l|l|l|l|l|l|l|l|l|}
\hline Scenario 0 & 0.580654575 & 0.575799412 & 0.595792651 & 0.2995659 & 0.309 & 0.285 & 0.3036772 & 0.554 & 7 \\
\hline Scenario 1 & 0.639042489 & 0.606233124 & 0.562240071 & 0.5955412 & 0.3094282 & 0.2853794 & 0.3036772 & 0.313 & 11 \\
\hline Scenario 2 & 0.544810459 & 0.575799412 & 0.595792651 & 0.149783 & 0.3094282 & 0.2853794 & 0.3036772 & 0.668 & 6 \\
\hline Scenario 3 & 0.578390144 & 0.576089675 & 0.596878644 & 0.2995659 & 0.2947515 & 0.3143228 & 0.2996945 & 0.543 & 9 \\
\hline Scenario 4 & 0.578390144 & 0.576089675 & 0.596878644 & 0.149783 & 0.2947515 & 0.3143228 & 0.2996945 & 0.693 & 5 \\
\hline Scenario 5 & 0.639042489 & 0.606233124 & 0.562240071 & 0.5755359 & 0.2947515 & 0.3143228 & 0.2996945 & 0.323 & 10 \\
\hline
\end{tabular}




\begin{tabular}{l|l|l|l|l|l|l|l|l|l}
\hline \multicolumn{10}{c}{ End of Table 9c. } \\
\hline Scenario 6 & 0.580654575 & 0.575799412 & 0.595792651 & 0.2995659 & 0.2947515 & 0.3143228 & 0.2996945 & 0.544 & 8 \\
\hline Scenario 7 & 0.508966343 & 0.58384743 & 0.629999656 & 0 & 0.3094282 & 0.2853794 & 0.3036772 & 0.824 & 3 \\
\hline Scenario 8 & 0.506701912 & 0.584137692 & 0.631085649 & 0 & 0.2947515 & 0.3143228 & 0.2996945 & 0.813 & 4 \\
\hline Scenario 9 & 0.716058085 & 0.679294628 & 0.629999656 & 0 & 0.3094282 & 0.2853794 & 0.3036772 & 1.127 & 1 \\
\hline Scenario 10 & 0.717292425 & 0.680465595 & 0.631085649 & 0 & 0.2947515 & 0.3143228 & 0.2996945 & 1.120 & 2 \\
\hline
\end{tabular}

In the ratio system part of MOORA the ranking remains entirely the same if yes or no private incomes become more important compared to the importance of the transfer payments and the national public debt. What about the Reference Point?

9d. Reference Point Theory with Ratios: co-ordinates of the reference point equal to the maximal objective values

\begin{tabular}{c|c|c|c|c|c|c|c} 
rank \\
\hline$r_{i}$ & 0.71729243 & 0.68046560 & 0.63108565 & 0.0000 & 0.2947515 & 0.2853794 & 0.29969453 \\
\hline
\end{tabular}

9e. Reference Point Theory: Deviations from the reference point

\begin{tabular}{l|c|c|c|c|c|c|c|c|c} 
max. & \multicolumn{1}{c}{ min. } \\
\hline Scenario 0 & 0.13663785 & 0.105 & 0.0353 & 0.299566 & 0.014677 & 0.0000 & 0.00398265 & 0.299566 & 7 \\
\hline Scenario 1 & 0.07824994 & 0.07423247 & 0.06884558 & 0.5955 & 0.014677 & 0.0000 & 0.00398265 & 0.5955412 & 11 \\
\hline Scenario 2 & 0.17248197 & 0.10466618 & 0.035293 & 0.1498 & 0.014677 & 0.0000 & 0.00398265 & 0.172482 & 4 \\
\hline Scenario 3 & 0.13890228 & 0.10437592 & 0.03420701 & 0.299566 & 0.000 & 0.0289 & 0 & 0.299566 & 7 \\
\hline Scenario 4 & 0.13890228 & 0.10437592 & 0.03420701 & 0.149783 & 0.0000 & 0.0289 & 0 & 0.149783 & 3 \\
\hline Scenario 5 & 0.07824994 & 0.074 & 0.069 & 0.5755 & 0.0000 & 0.0289 & 0 & 0.575536 & 10 \\
\hline Scenario 6 & 0.13663785 & 0.10466618 & 0.035293 & 0.299566 & 0.0000 & 0.0289 & 0 & 0.299566 & 7 \\
\hline Scenario 7 & 0.20832608 & 0.09661817 & 0.00108599 & 0 & 0.014677 & 0.0000 & 0.00398265 & 0.20833 & 5 \\
\hline Scenario 8 & 0.21059051 & 0.09632790 & 0 & 0 & 0 & 0.028943 & 0 & 0.21059 & 6 \\
\hline Scenario 9 & 0.00123434 & 0.00117097 & 0.00108599 & 0 & 0.014677 & 0.000000 & 0.00398265 & 0.014677 & 1 \\
\hline Scenario 10 & 0 & 0 & 0 & 0 & 0 & 0.028943 & 0 & 0.02894 & 2 \\
\hline
\end{tabular}

The ranking of the Reference Point is different from the ranking of the Ratio System Part when a Significance Coefficient of 2 is allotted to the Private Income of each of the three regions.

Scenarios 9 and 10 are again first ranked which is unrealistic. The other regions try to arrive at the high level of Flanders, which is impossible given the fact that the transfer payments are abolished and the economic structure of Wallonia and Brussels is too weak.

Scenario 4 is ranked $3^{\text {rd }}$. As mentioned above due to an unfavourable growth and inflation rate in order not to destabilize its own economy Flanders has to diminish the transfer payments significantly, namely to 2.92 billion $€$. In addition Flanders asks for a new repartition of the national public debt.

Scenario 2 is ranked $4^{\text {th }}$. The situation is comparable with the previous scenario. Nevertheless the solidarity in the national public debt is kept unchanged.

Scenario 7 is ranked $5^{\text {th }}$. The transfer payments disappear entirely but solidarity remains for the National Public Debt.

Scenario 8 is ranked $6^{\text {th }}$. The transfer payments disappear and no solidarity remains for 
the National Public Debt. This scenario could mean a move either from a federal state to a confederation of states or to complete secession.

Scenario 3 is ranked $7^{\text {th }}$. The national public debt is reapportioned again and the transfer payments are halved.

If the significance coefficient of 2 on the private incomes gives a certain difference in the reference point part compared to the ratio system part of MOORA, the diminishment and even the complete abolition of the transfer payments remains essential.

\section{References}

Admati, A. R.; Pfleiderer, P. 1994. Robust Financial Contracting and the Role of Venture Capitalists, Journal of Finance 49(2): 371-402. doi:10.2307/2329157

Arrow, K. J. 1974. General Economic Equilibrium: Purpose, Analytic Techniques, Collective Choice, American Economic Review, June: 253-272.

Brauers, W. K.; Zavadskas, E. K. 2010. Is Robustness really Robust? Robustness from the Point of View of Statistics and Econometrics, in C. Zopounidis, M. Doumpos, et al. Multiple Criteria Decision Aiding. NOVA Science Publishers, Chapter 2.

Brauers, W. K. 2008a. Group Decision Making With Multi-Objective Optimization, Foundations of Computing and Decision Sciences 33(2): 167-179.

Brauers, W. K. 2008b. Multi-Objective Decision Making by Reference Point Theory for a Wellbeing Economy, Operations Research International Journal 8(1): 89-104. doi:10.1007/s12351-008-0013-7 Brauers, W. K. 2007. What is Meant by Normalization in Decision Making? International Journal of Management and Decision Making 8(5/6): 445-460. doi:10.1504/IJMDM.2007.013411

Brauers, W. K.; Zavadskas, E. K. 2006. The MOORA Method and its Application to Privatization in a Transition Economy, Control and Cybernetics 35(2): 445-469.

Brauers, W. K. 2004. Optimization Methods for a Stakeholder Society. A Revolution in Economic Thinking by Multiobjective Optimization. Kluwer Academic Publishers and Springer, Boston.

Brauers, W. K. 2002. The Multiplicative Representation for Multiple Objective Optimization with an Application for Arms Procurement, Naval Research Logistics: an International Journal 49(4): 327-340. doi:10.1002/nav.10014

Brauers, W. K. 1999a. Het Bruto Regionale Product van Vlaanderen, Wallonie en Brussel (the GRP of Flanders, Wallonia and Brussels). Working Paper 99/2, University of Antwerpen (RUCA) Antwerpen.

Brauers, W. K. 1999b. Een optimaal economisch beleid voor België en zijn gewesten volgens de multipele effectiviteitsanalyse (An optimal economic policy for Belgium using a Multi-Objective Analysis), Documentatieblad 59(5): 3-24. Department of Finance.

Brauers, W. K. 1987. Nominal Methods in Group Multiple Decision Making. Research Paper `o3, Institute for Developing Countries, University of Antwerp, RUCA, Antwerpen.

Brauers, W. K.; Van Waterschoot, J.; Van Elewyck, P. 1979. De Sectoriële en Regionale Analyse van de Belgische Economie (the sectoral and regional analysis of the Belgian economy). KUL, Leuven.

Carter Hill, R.; Griffiths, W. E.; Lim, G. C. 2008. Principles of Econometrics. John Wiley and Sons, Hoboken NJ.

Casella, G.; Berger, R. L. 2002. Statistical Inference. 2nd ed. Pacific Grove, Ca, US, Duxbury, Thomson Learning.

Churchman, C. W.; Ackoff, R. L; Arnoff E. L, 1957. Introduction to Operations Research. New York, Wiley.

Churchman, C. W.; Ackoff, R. L. 1954. An Approximate Measure of Value, Operations Research 2: $172-180$. 
Condorcet, Marquis de1. 1785. Essai sur l'application de l'analyse à la probabilité des décisions rendues à la pluralité des voix. Paris, l'Imprimerie royale.

Dalkey, N.; Helmer, O. 1963. An Experimental Application of the Delphi Method to the use of Experts, Management Science: 458-487. doi:10.1287/mnsc.9.3.458

Darnell, A. C. 1997. Dictionary of Econometrics. Cheltenham, UK, Edward Elgar.

Dasgupta, P.; Maskin, E. 2008. On the Robustness of Majority Rule, Journal of the European Economic Association 6(5): 949-973. doi:10.1162/JEEA.2008.6.5.949

Dury, D.; Eugène, B.; Lagenus, G.; Van Cauter, K.; Van Meensel, L. 2008. Intergewestelijke Overdrachten en Solidariteitsmechanismen via de Overheidsbegroting (Interregional Transfer Payments and mechanisms of Solidarity in the Public budget), Economisch Tijdschrift. National Bank of Belgium, September.

Edin, P. A.; Ohlson, H. 1991. Political Determinants of Budget Deficits: Coalition Effects versus Minority Effects, European Economic Review 35(8): 1597-1603. doi:10.1016/0014-2921(91)90021-A

Frisch, R. 1933. Pitfalls in the Statistical Construction of Supply and Demand Curves, Veröffentlichungen der Frankfurter Gesellschaft für Konjuncturforschung, New Series, V(II), Leipzig, Germany, Hans Buske.

Gossen, H. H. 1853. Entwicklung der gesetze des Menschlichen Verkehrs und der daraus Flieszenden Regeln für Menschliches Handeln. 3 Auflage, Prager, Berlin.

Hays, W. L. 1974. Statistics for the Social Sciences. London, Holt, Rinehart and Winston.

Heckman, J. J. 1992. Havelmo and the Birth of Modern Econometrics, Journal of Economic Literature 30: 878 .

Hoel, P. G. 1971. Elementary Statistics. New York, Wiley.

Huber, P. J. 1981. Robust Statistics. New York, Wiley.

Huber, P. J. 1969. Theorie de l'Inference Statistique Robuste. Montreal, les Presses de l'Universite de Montreal.

Hwang, C. L.; Yoon, K. 1981. Multiple Attribute Decision Making, Methods and Applications. Springer-Verlag, Berlin.

Intriligator, M. D. 1978. Econometric Models, Techniques and Applications. Amsterdam, North Holland.

Johnston, J. 1963. Econometric Models. New York, US, Mcgraw Hill.

Karlin, S.; Studden, W. J. 1966. Tchebycheff Systems: with Applications in Analysis and Statistics. New York, Interscience Publishers.

Keeney, R. L.; Raiffa, H. 1993. Decisions with Multiple Objectives. Preferences and Value Tradeoffs. Cambridge University Press, USA.

Kendall, M. G. 1948. Rank Correlation Methods. Griffin, London.

Kendall, M. G.; Gibbons, J. D. 1990. Rank Correlation London, Edward Arnold.

Kennedy, P. 1998. A Guide to Econometrics. Oxford, Blackwell.

Kreps, D. M. 1990. Game Theory and Economic Modelling. Oxford, Oxford University Press and Clarendon Press. doi:10.1093/0198283814.001.0001

Machina, M. J.; Schneider, D. A. 1992. More Robust Definition of Subjective Probability, Econometrica 60(4): 745-80. doi:10.2307/2951565

Madansky, A. 1976. Foundations of Econometrics. Amsterdam N1, North Holland.

Matyas, L.; Semestre, P. 1992. The Econometrics of Panel Data, Handbook of Theory and Applications, Advanced Studies in Theoretical and Applied Econometrics, vol. 28, Dordrecht, N1., Kluwer Academic Publishers.

Miller, D. W; Starr, M. K. 1969. Executive Decisions and Operations Research. 2nd ed. Prentice-Hall Inc. Englewood Cliffs (N.J.). 
Mills, J. A. 1992. Bayesian Prediction Tests for Structural Stability, Journal of Econometrics 52(3): 381-388. doi:10.1016/0304-4076(92)90018-M

Minkowsky, H. 1896. Geometrie der Zahlen. Teubner, Leipzig.

Minkowsky, H. 1911. Gesammelte Abhandlungen. Teubner, Leipzig.

Pareto, V. 1906. Manuale di Economia Politica, Translation revised by Pareto himself: Manuel d'économie politique. 2nd ed. Paris.

Quade, 1970. Cost-Effectiveness: Some Trends in Analysis. Rand Corporation, P-3529-1, Santa Monica (CAL).

Quade, E. S.; Boucher, W. I. 1968. Systems Analysis and Policy Planning: Applications in Defense. Elsevier, New York.

Rieder, H. (Ed.). 1996. Robust Statistics, Data Analysis and Computer Intensive Methods. New York, Springer.

Rhodes, G. F.; Fomby, T. B. (Eds.). 1988. Nonparametric and Robust Inference. Greenwich, Conn., US, JAI Press.

Roy, B.; Benayoun, R.; Sussman, B. 1966. ELECTRE, Société d'Economie et de Mathématique appliquées. Paris.

Ruggeri, F. 2008. Bayesian Robustness, European Working Group, Multiple Criteria Decision Aiding 3(17): 6-10.

Särndal, C.-E.; Swensson, B.; Wretman, J. 1992. Model Assisted Survey Sampling. New York, Springer. Saaty, T. L. 1988. The Analytic Hierarchy Process. Mcgraw-Hill, New York.

Stigler, S. 1973. Simon Newcomb, Percy Daniell and the History of Robust Estimation 1885-1920, Journal of the American Statistical Association 68: 872-879. doi:10.2307/2284515

Taguchi, G. 1993. On Robust Technology Development: bringing Quality Engineering Upstream. ASME Press, New York.

Tinbergen, J. 1930. Bestimmung und Deutung von Angebotskurven, Zeitschrift für Nationalökonomie 1(1): 669-679. doi:10.1007/BF01318500

Thomas, R. L. 1985. Introductory Econometrics. London, Longman.

Van de Ven, A. H.; Delbecq, A. L. 1971. Nominal versus Interacting Group Processes for Committee Decision Making Effectiveness, Academy of Management Journal 14(2): 203-212. doi:10.2307/255307

Van Gompel, J.; Van Craeynest, B. 2003. Financiële transfers tussen de Belgische Gewesten herbekeken. Reviewing transfer payments between the Belgian Regions, KBC asset Management.

Van Rompuy, P.; Bilsen, V. 1988. Tien jaar financiële stromen tussen de Gewesten (Ten years of transfer payments between the regions), Leuvense Economische Standpunten 45.

Verbeek, M. 2008. A Guide to Modern Econometrics. John Wiley and Sons, Hoboken NJ.

Vincke, P. 1999. Robust Solutions and Methods in Decision Aid, Journal of Multi-Criteria Decision Analysis 8(3): 181-187. doi:10.1002/(SICI)1099-1360(199905)8:3<181::AID-MCDA242>3.0.CO;2-P

Walters, A. A. 1973. An Introduction to Econometrics. London, Macmillan.

Wierzbicki, A. P.; Makowski, M. 1992. Multi-Objective Optimization in Negotiation Support, WP-92007, IASA, Laxenburg.

Wonnacott, R. J.; Wonnacott, T. H. 1970. Econometrics. New York, Wiley.

Belgische Grondwet (Belgian Constitution) [online] 1994. Brussels. Department of Finance of Belgium, Study and Documentation Service, Documentatieblad, Brussels.FOD, Economics, General Direction Statistics and Economic Information, Eurostat, Luxemburg [cited 3 March 2010]. Available from Internet: $<$ www.senate.be $>$.

Forum [online]. 2009. Walloon Administration for Labor Promotion, service public wallon de l'emploi et de la formation [cited 3 March 2010]. Available from Internet: htpp://wwww.leforum.be. 


\title{
BELGIJOS REGIONŲ EKONOMIKA, IVERTINTA TAIKANT MULTIMOORA METODA
}

\author{
W. K. M. Brauers, R. Ginevičius
}

\section{Santrauka}

Stiprumo apibrēžimas ekonometrijoje, klaidos terminas linijinėje lygtyje buvo ne tik išplèstas, jo reikšmè buvo perkelta i paprastą kalba, t. y. nuo kiekybinès iki kokybinès reikšmès. Šiuo metu stipriausi daugiatiksliai optimizavimo metodai turi atitikti septynias pagrindines sąlygas. Be to, turint omenyje visas suinteresuotas grupes, tikslų pasirinkimas yra objektyvus taikant patobulintą nominalių grupių ir Delphi metodus. Normalizavimas privalo būti taip pat objektyvus, tai i̇manoma padaryti naudojant dauginamają MOORA (daugiatikslis optimizavimas remiantis santykio analize) metodo formą. Ji susideda iš santykio analizès „senso strigto“ ir atskaitos taško metodo su anksčiau gautu santykiu kaip pradžios tašku. Taigi sujungus tris metodus, kaip stiprumo garantas buvo pasiūlytas MULTIMOORA. Šis metodas yra išbandytas tiriant Belgijos regionų ekonomiką.

Reikšminiai žodžiai: stiprumas, daugiatikslis optimizavimas, suinteresuotos grupès, patobulintas nominalių grupių metodas. Delphi metodas, pilnas sandaugos būdas, MOORA, MULTIMOORA.

Willem K. M. BRAUERS graduated as: Ph.D. in Economics (Un. of Leuven), Master of Arts (in Economics) of Columbia Un. (New York), Master in Management and Financial Sciences, in Political and Diplomatic Sciences and Bachelor in Philosophy (Un. of Leuven). He is professor ordinarius at the Faculty of Applied Economics and at the Institute for Development Policy and Management of the University of Antwerp, Honorary Professor at the University of Leuven, the Belgian War College, the School of Military Administrators and the Antwerp Business School. He was a research fellow in several American institutions like Rand Corporation, the Institute for the Future, the Futures Group and extraordinary advisor to the Center for Economic Studies of the University of Leuven. He was consultant in the public sector, such as the Belgian Department of National Defense, the Department of Industry in Thailand, the project for the construction of a new port in Algeria (the port of Arzew) and in the private sector such as the international seaport of Antwerp and in electrical works. He was Chairman of the Board of Directors of SORCA Ltd.Brussels, Management Consultants for Developing Countries, linked to the worldwide group of ARCADIS and Chairman of the Board of Directors of MARESCO Ltd. Antwerp, Marketing Consultants. At the moment he is General Manager of CONSULTING, Systems Engineering Consultants. Brauers is member of many international scientific organizations. His specialization covers: Optimizing Techniques with Different Objectives, Forecasting Techniques, Input-Output Techniques and Public Sector Economics such as for National Defense and for Regional Sub-optimization. His scientific publications consist of twelve books and hundreds of articles and reports.

Romualdas GINEVIČIUS. Professor, Dr, Head of the Department of Enterprise Economics and Management, construction engineer and economist. The author of more than 350 research papers and over 20 scientific books; editor-in-chief of the 'Journal of Business Economics and Management' (located in ISI database 'Web of Science') and the journal 'Business: Theory and Practice'. Research interests: organization theory, complex quantitative evaluation of social processes and phenomena. 